\title{
Eusebius of Caesarea, the Roman Empire, and the Fulfillment of Biblical Prophecy: Reassessing Byzantine Imperial Eschatology in the Age of Constantine
}

\author{
Christopher Bonura \\ Department of History, University of California, Berkeley, California, USA \\ Email: bonura@berkeley.edu
}

\begin{abstract}
Modern scholarship often attributes to Eusebius of Caesarea (d. circa 340 AD) the view that God's heavenly kingdom had become manifest in the Roman Empire of Constantine the Great. Consequently, Eusebius is deemed significant in the development of Christian eschatological thought as the supposed formulator of a new "realized eschatology" for the Christian Roman Empire. Similarly, he is considered the originator of so-called "Byzantine imperial eschatology" - that is, eschatology designed to justify the existing imperial order under the emperors in Constantinople. Scholars advancing these claims most frequently cite a line from Eusebius's Tricennial Oration in which he identified the accession of the sons of Constantine with the prophesied kingdom of the saints in the Book of Daniel. Further supposed evidence has been adduced in his other writings, especially his Life of Constantine. This article argues that this common interpretation of Eusebius's eschatology is mistaken and has resulted from treating a few passages in isolation while overlooking their rhetorical context. It demonstrates instead that Eusebius adhered to a conventional Christian eschatology centered on the future kingdom of heaven that would accompany the second coming of Christ and further suggests that the concept of "Byzantine imperial eschatology" should be reconsidered.
\end{abstract}

Keywords: Eschatology; Eusebius; Constantine; Apocalypticism

This paper was awarded the Sidney E. Mead Prize for the best unpublished article stemming from dissertation research that contributes significantly to its field and to the history of Christianity more broadly.

This article began as a chapter in my dissertation, the preliminary research for which was made possible by a junior fellowship at the Dumbarton Oaks Museum and Research Library. I am grateful to my dissertation committee for their help and guidance, and especially to Maria Mavroudi and Susanna Elm for their encouragement and for providing feedback on draft versions of this article. Special thanks are due to the Michael Hollerich and David Devore, as well as the anonymous reviewers, for suggestions. Thanks also to Jess Farrell for excellent copyediting. Finally, my deepest gratitude to Andrea Sterk for being both a great teacher and editor and for helping shepherd this article through the publication process.

(C) The Author(s), 2021. Published by Cambridge University Press on behalf of American Society of Church History. This is an Open Access article, distributed under the terms of the Creative Commons Attribution licence (http://creativecommons.org/licenses/by/4.0/), which permits unrestricted re-use, distribution, and reproduction in any medium, provided the original work is properly cited. 


\section{Introduction: Eusebius and Byzantine Eschatology}

In the summer of $336 \mathrm{AD}$, officials and churchmen from all over the Roman world gathered in the new capital on the Bosporus to celebrate the thirtieth regnal year of its namesake, Emperor Constantine. The one surviving document from that occasion is the text of a panegyric (the Tricennial Oration) delivered in the presence of the emperor and his household at the closing ceremony by Eusebius, bishop of Caesarea. ${ }^{1}$ One of the most brilliant and prolific writers of late antiquity, Eusebius had written biblical commentaries and incisive apologies, invented the genre of church history, and pioneered the Christian world chronicle. Now he turned his formidable mind to the ancient rhetorical art of royal praise.

Drawing on Hellenistic theories of kingship, Eusebius put forth a vision of empire and the imperial office fit for the new, Christian imperial era. ${ }^{2}$ Modern scholars have characterized Eusebius's ideas in the Tricennial Oration as an influential new Christian theory of politics, ${ }^{3}$ but also as a starting point for the ill-starred union of church and state, or even the subordination of the church to the state and theology to political ideology. ${ }^{4}$ Moreover, since Eusebius suggested an orderly universe in which God and Christ ruled in heaven and Constantine ruled on earth, he has been accused of leaving little room for the incarnate Christ who died on the cross. ${ }^{5}$

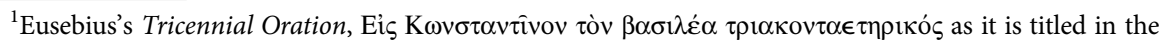
manuscripts (or, as it is sometimes called in secondary scholarship, Oratio de laudibus Constantini-In Praise of Constantine), survives attached to several of the manuscript copies of Eusebius's Life of Constantine. Critical edition in Eusebius Werke, vol. 1, Über das Leben Constantins, Rede an die heilige Versammlung, Tricennatsrede an Constantin, ed. Ivar Heikel (Leipzig: Hinrichs, 1902), 195-259. A detailed study, with an English translation, is available in H. A. Drake, In Praise of Constantine: A Historical Study and New Translation of Eusebius' Tricennial Orations (Berkeley: University of California Press, 1976). Although often published in eighteen chapters, where I refer to the Tricennial Oration, I only refer to the first ten chapters; chapters 11-18 appear to be a separate panegyric, commonly identified as that delivered by Eusebius at the dedication of the Church of the Holy Sepulcher in Jerusalem; see Heikel, Eusebius Werke, 1:civ-cvi; Drake, In Praise of Constantine, 30-45; and T. D. Barnes, "Two Speeches by Eusebius," Greek, Roman and Byzantine Studies 18, no. 4 (1977): 341-345.

${ }^{2}$ The importance of the Tricennial Oration to Christian-Roman and Byzantine notions of rulership and its basis in Hellenistic philosophy was first proposed in Norman Baynes, "Eusebius and the Christian Empire," Annuaire de l'institut de philologie et d'histoire orientales 2 (1933): 13-18. On Hellenistic political philosophy in Christianity and the Christian Roman Empire, see Francis Dvornik, Early Christian and Byzantine Political Philosophy: Origins and Background (Washington, D.C.: Dumbarton Oaks Center for Byzantine Studies, 1966), 2:205-277, 611-658.

${ }^{3}$ In "Eusebius and the Christian Empire," Baynes asserted that Eusebius's Tricennial Oration was the starting point of Byzantine political thought. This view has been widely accepted. For example, Dvornik, Early Christian and Byzantine Political Philosophy, 2:616, states: "Eusebius laid the foundations for the Byzantine political structure and for Eastern policies on the relationship between Church and state." Steven Runciman, The Byzantine Theocracy (Cambridge: Cambridge University Press, 1977), also portrays Eusebius's political theories as vital for Byzantium, speaking of its "Eusebian constitution." However, Anthony Kaldellis, The Byzantine Republic: People and Power in New Rome (Cambridge, Mass.: Harvard University Press, 2015), 177, disputes the idea that Eusebius's theories had much influence in Byzantium, and urges scholars "to stop treating Eusebios as the Founding Father of Byzantine thought."

${ }^{4}$ See Gerhard Ruhbach, "Die politische Theologie des Eusebs von Caesarea," in Die Kirche angesichts der Konstantinischen Wende, ed. Gerhard Ruhbach (Darmstadt: Wissenschaftliche Buchgesellschaft, 1976), 236-258, where Ruhbach enumerates such opinions, while convincingly countering them.

${ }^{5}$ Hans Eger, "Kaiser und Kirche in der Geschichtstheologie Eusebs von Cäsarea," Zeitschrift für die Neutestamentliche Wissenschaft und die Kunde der Älteren Kirche 38 (1939): 113-114; and Michael
} 
A somewhat more forceful corollary to this argument holds that Eusebius also displaced the triumphant Christ of the second coming. In place of the Christ of the Parousia, according to some scholars, Eusebius elevated Constantine and his heirs. ${ }^{6}$ And in place of the eternal kingdom of heaven that Christians had awaited, Eusebius supposedly elevated the Roman Empire. Proponents of this view typically cite several works in Eusebius's corpus, but the centerpiece of this position has become one passage in the Tricennial Oration. Here, Eusebius praises Constantine for promoting his sons as his dynastic heirs:

And He [God] allows him [Constantine] to carry out every one of his celebrations with great relief from the burden of sole rule, having readied some one of his sons for partnership in the royal throne at each tenth anniversary.... And so, by the appointment of the Caesars [by Constantine], He [God] fulfills the predictions of the divine prophets, which ages and ages ago proclaimed that "the saints of the Most High shall take up the kingdom."7

Eusebius quotes here from the Old Testament Book of Daniel (chapter 7), ${ }^{8}$ in which the prophet Daniel sees in a dream four beasts emerge from the sea. The fourth beast is described in explicitly negative terms, devouring its victims with iron teeth and trampling their remains underfoot. An ancient figure appears on a fiery throne and condemns the fourth beast to be burned. Then, a figure in the form of a man (a "son of man") comes from heaven, and the ancient figure invests him with authority to establish a kingdom that will never be destroyed. When Daniel awakens, an angel explains that the beasts are the four successive kingdoms that will rule the earth. The fourth is the worst of them, but God will destroy it and replace it with an eternal kingdom, wherein "the saints of the Most High shall take up the kingdom; their kingdom shall be an everlasting kingdom" (Daniel 7:27). This vision echoes Daniel 2, in which Daniel interprets King Nebuchadnezzar's dream of a statue made of four metals (with head of gold, chest of silver, belly and thighs of bronze, and legs of iron) smashed by a great stone. According to Daniel, the four metals represent the four kingdoms of the earth, like the beasts in Daniel 7. The stone signifies an everlasting kingdom that would replace them.

J. Hollerich, Eusebius of Caesarea's Commentary on Isaiah: Christian Exegesis in the Age of Constantine (Oxford: Clarendon, 1999), 192.

${ }^{6}$ See, for example, David A. Lopez, Separatist Christianity: Spirit and Matter in the Early Church Fathers (Baltimore: Johns Hopkins University Press, 2004), 145-147.

${ }^{7}$ Eusebius, Tricennial Oration 3.1-2, in Heikel, Eusebius Werke, 1:200-201: " $\pi \alpha \rho \varepsilon ́ \chi \varepsilon 1 ~ \tau \varepsilon ~ \pi \alpha v \tau o i ́ \alpha \varsigma$

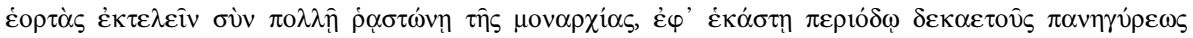

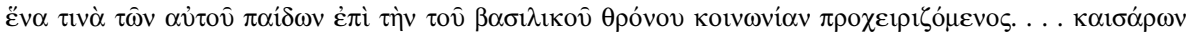

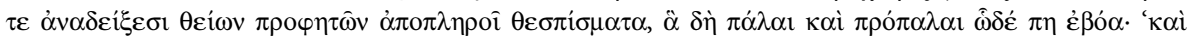

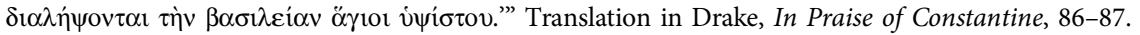

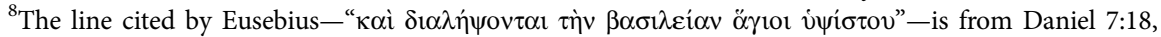

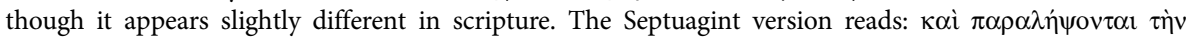

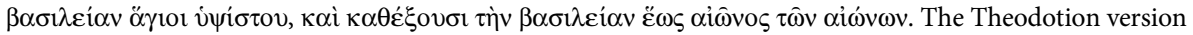

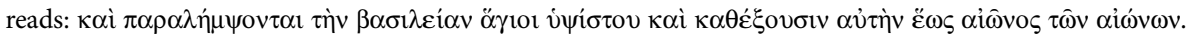
See The Old Testament in Greek According to the Septuagint, ed. Henry Barclay Swete (Cambridge: Cambridge University Press, 1905), 3:548-549. Eusebius almost certainly would have utilized the Theodotion version of Daniel, since it was widely regarded as the authoritative Greek version, and it replaced the Septuagint translation of Daniel (which remains very rare) even in copies of the Septuagint. 
The Book of Daniel was composed (perhaps utilizing earlier material) circa 163 BC at a time when the Jews were suffering persecution at the hands of the Hellenistic king Antiochus IV Epiphanes. In this original context, the fourth kingdom was evidently intended to represent the empire of Alexander the Great and his successors and the fifth kingdom a future Jewish kingdom that God would grant his chosen people in recompense for their suffering. ${ }^{9}$ However, as time passed and the Roman Empire became the sole Mediterranean superpower (and especially after the Roman sack of Jerusalem in 70 AD), Jewish authors widely identified Rome as the fourth kingdom prophesied by Daniel. ${ }^{10}$ The early Christian community, which was emerging from Judaism and suffering sporadic persecution by the Romans, adopted this interpretation.

The Book of Daniel long remained the most important source for Christian eschatological thought. The earliest surviving commentary on Daniel, written in Greek around 223-235 AD and attributed to Hippolytus of Rome, reiterated several times that Rome was the fourth kingdom in Daniel's vision ${ }^{11}$ and, as such, would be destroyed and replaced by a fifth. ${ }^{12}$ In this Christian interpretation, however, the fifth kingdom was not a future Jewish state but the eschatological kingdom that would dawn with Christ's second coming. ${ }^{13}$ Other early Christian exegetes such as Lactantius shared a similar view: ${ }^{14}$ Rome was the evil fourth kingdom (represented in Daniel 2 by the iron portions of the statue and in Daniel 7 by the fourth beast), and the fifth kingdom (represented by the stone that smashes the statue in Nebuchadnezzar's dream and by the "son of man" in Daniel's dream) was Christ's eschatological kingdom. ${ }^{15}$

Eusebius's thinking is often represented as initiating a radical break from this interpretative tradition, making him a transformative figure for the development of Christian eschatology. By identifying the saints of the Most High (Daniel 7) with the sons of Constantine, he seemed to suggest that the Roman Empire had transformed from the fourth beast into the eternal fifth kingdom. A weak version of this thesis holds that Eusebius-as a worldly thinker who sought to reconcile Christianity with Roman civilization-was simply attempting to downplay the embarrassing apocalyptic content

\footnotetext{
${ }^{9}$ There are enough textual clues in the Book of Daniel to identify the four kingdoms in Daniel 2 and 7 as the Babylonians, Medes, Persians, and the Greco-Macedonian Empire of Alexander the Great. See, for example, C. C. Caragounis, "History and Supra-History: Daniel and the Four Empires," in The Book of Daniel in the Light of New Findings, ed. A. S. van der Woude (Leuven: Leuven University Press, 1993), 387-397.

${ }^{10}$ Such identification is evident in Jewish apocalyptic texts of the late first and second century, especially 4 Ezra and 2 Baruch. See also Maurice Casey, Son of Man: The Interpretation and Influence of Daniel 7 (London: SPCK, 1979), 80-92; and Uwe Glessmer, "Die 'vier Reiche' aus Daniel in der targumischen Literatur," in The Book of Daniel: Composition and Reception, ed. John J. Collins and Peter W. Flint (Leiden: Brill, 2001), 2:468-489.

${ }^{11}$ Hippolytus, Commentary on Daniel 4.3.1-4.8.7, 4.12.3-4, 4.21.1-4. On the date of the commentary, see Allen Brent, Hippolytus and the Roman Church in the Third Century: Communities in Tension before the Emergence of a Monarch-Bishop (Leiden: Brill, 1995), 278-279. Although the authorship of the Hippolytan corpus has long been disputed, I refer to the author as "Hippolytus," acknowleding that this may not have been his real name.

${ }^{12}$ Hippolytus, Commentary on Daniel 4.6.4, 4.12.4, 4.23.3-5, 4.24.7.

${ }^{13}$ Hippolytus, Commentary on Daniel, 4.23.5.

${ }^{14}$ Lactantius, Divine Institutes, 7. Notably, Lactantius does not explicitly mention Daniel, but his eschatology is deeply influenced by the symbolism of Daniel 2 and 7.

${ }^{15}$ At the end of the fourth century, both Cyril of Jerusalem and Jerome offered up this interpretation, and both (Cyril, Catechetical Lectures, 15.12; and Jerome, Commentary on Daniel, 2.7:8) described it as the interpretation handed down by all the teachers of the church.
} 
of Christianity by identifying an eschatological vision of a new earthly order with the peaceful succession of the reigning emperors. ${ }^{16}$ A stronger thesis, however, has become increasingly prevalent: Eusebius suggested that the eternal kingdom of heaven really had arrived in the form of the Roman Empire itself, with Constantine replacing Christ as the herald and ruler of that kingdom. Thus, according to a recent monograph by Stephen Shoemaker: "Eusebius [in the Tricennial Oration] equates Constantine with Christ, and likewise, the empire with Christ's heavenly Kingdom. In effect, the coming of the Kingdom of God that Christ promised has now been realized, according to Eusebius, in the Roman Empire."17

Eusebius's eschatological views, therefore, have been characterized as "realized eschatology" or "imperial eschatology." 18 This terminology has its roots in New Testament studies. The theologian C. H. Dodd coined the term "realized eschatology" in 1935 to describe his interpretation of Jesus's message in the Gospels-namely, that the kingdom of heaven lay not in the future, at the end of time, but was manifest in Jesus's ministry. ${ }^{19}$ Applied to Eusebius, the term suggests that his message was that the kingdom of heaven was already manifest in the rule of Constantine and his successors. The concept of "imperial eschatology" has been popularized in scholarship on the apostle Paul, whose eschatological pronouncements about the glorious adventus of Christ at his second coming contrasts with the pagan notion of "imperial eschatology" focusing on the emperor's apotheosis. ${ }^{20}$ When scholars allege that Eusebius formulated Christian "imperial eschatology," they suggest that he provided a new Christian veneer to an old pagan system of glorifying emperor and empire. This has wide implications, because Eusebius's supposed outlook, whether classified as "realized eschatology" or Christianized "imperial eschatology," is often treated as the prototype for eschatology in the Byzantine Empire and the medieval Orthodox Church.

One of the most influential works propagating this view has been Gerhard Podskalsky's 1972 study of eschatology in the Byzantine Empire. Podskalsky contrasted "Byzantine" eschatology with the "Christian" eschatology found in the Gospels, the writings of Paul, and elsewhere in scripture. According to Podskalsky, Christian eschatology looked forward to the upending of the current order and the establishment of a

\footnotetext{
${ }^{16}$ See, for example, Hans-Georg Opitz, "Euseb von Caesarea als Theologe: Ein Vortrag," Zeitschrift für die Neutestamentliche Wissenschaft und die Kunde der Älteren Kirche 34 (1935): 1-19, esp. 13-14; and Jean Sirinelli, Les vues historiques d'Eusèbe de Césarée durant la période prénicéenne (Dakar: Université de Dakar, 1961), 455-486.

${ }^{17}$ Stephen J. Shoemaker, The Apocalypse of Empire: Imperial Eschatology in Late Antiquity and Early Islam (Philadelphia: University of Pennsylvania Press, 2018), 40.

${ }^{18}$ The term "realized eschatology" seems to be preferred by the advocates of the weaker version of the argument described above. Ruhbach, "Die politische Theologie," 253, refers to Eusebius's "realisierte Eschatologie," though he questions the traditional interpretation of Eusebius as an uncritical apologist for Constantine and the Roman Empire. Brian E. Daley, The Hope of the Early Church: A Handbook of Patristic Eschatology (Cambridge: Cambridge University Press, 1991), 77, talks of Eusebius's "realized eschatology," though he specifies that Eusebius viewed the end of persecution and the Christianization of the empire simply as "a foretaste of the eternal Kingdom." Hollerich, Eusebius of Caesarea's Commentary on Isaiah, 196-201, speaks of Eusebius's "realized eschatology," but argues that Eusebius saw the church and clergy-far more than the empire or emperor-as the fulfillment of prophecy.

${ }^{19}$ C. H. Dodd, The Parables of the Kingdom (London: Nisbet and Co., 1935).

${ }^{20}$ See, for example, James R. Harrison, Paul and the Imperial Authorities at Thessalonica and Rome: A Study in the Conflict of Ideology (Tübingen: Mohr Siebeck, 2011), 88-89; and J. Brian Tucker, "Remain in Your Calling": Paul and the Continuation of Social Identities in 1 Corinthians (Eugene: Pickwick, 2011), 201-208.
} 
utopian kingdom of heaven, while Byzantine eschatology sought only to justify the continued existence of imperial power. ${ }^{21}$ Podskalsky pointed to Eusebius and his Tricennial Oration as one of the main starting points of "Byzantine" eschatology: "Eusebius did not shy away in his Tricennial speech from correlating the verse the saints of the Most High shall take up the kingdom' (Daniel 7:18) to Constantine's accession to power.... Thereby, not in words but in substance, the Roman Empire had merged with the kingdom of Christ." 22

Podskalsky's study remains the most important survey of eschatology in Byzantium and the medieval Orthodox Church, and it has influenced some of the finest scholars of late antiquity and the Byzantine Empire. As a result, it has become increasingly common to treat Eusebius's supposed identification of the earthly empire with the heavenly kingdom as the foundation of Byzantine political thought and of the political theology of medieval Orthodoxy. The great scholar of Orthodoxy John Meyendorff has suggested that: "Byzantine theocratic thought was, in fact, based upon a form of 'realized eschatology,' as if the Kingdom of God had already appeared 'in power' and as if the empire were the manifestation of this power in the world and in history." 23 According to the Byzantine historian Paul Magdalino, most Romans/Byzantines eventually "saw the Kingdom of Heaven as being both imminent and immanent in the Christian Empire." ${ }^{24} \mathrm{He}$ attributes this view to the increasing identification of the empire with the heavenly fifth kingdom, and further claims that this "interpretation of the Four Kingdoms prophecy in the Book of Daniel. . . had been hinted at by Eusebius in the fourth century." 25 Many others have echoed these views. ${ }^{26}$

Nonetheless, all these characterizations misrepresent the political thought of the Christian Roman/Byzantine Empire. With the possible exception of a few marginal figures, no Byzantines identified the empire as God's eternal kingdom, nor did they believe that the emperor had replaced Christ, christomimetic though his office might be. A reevaluation of Byzantine eschatology is necessary, and as a preliminary step in this larger project, this article will show that the supposed founder of Byzantine imperial

\footnotetext{
${ }^{21}$ Gerhard Podskalsky, Byzantinische Reichseschatologie: Die Periodisierung der Weltgeschichte in den vier Grossreichen (Daniel 2 und 7) und dem tausendjährigen Friedensreiche (Apok. 20); Eine motivgeschichtliche Untersuchung (Munich: Wilhelm Fink, 1972), esp. 70-76, 101-103.

${ }^{22}$ Podskalsky, Byzantinische Reichseschatologie, 10-12. My translation; unless otherwise noted, all translations are my own.

${ }^{23}$ John Meyendorff, Byzantine Theology: Historical Trends and Doctrinal Themes (New York: Fordham University Press, 1974), 214.

${ }^{24}$ Paul Magdalino, "The History of the Future and Its Uses: Prophecy, Policy and Propaganda," in The Making of Byzantine History: Studies Dedicated to Donald M. Nicol on His Seventieth Birthday, ed. Roderick Beaton and Charlotte Roueché (Aldershot: Variorum, 1993), 11.

${ }^{25}$ Magdalino, "History of the Future," 10. See also Paul Magdalino, ed., Byzantium in the Year 1000 (Leiden: Brill, 2003), 250.

${ }^{26}$ Dimiter Angelov and Judith Herrin, “The Christian Imperial Tradition: Greek and Latin,” in Universal Empire: A Comparative Approach to Imperial Culture and Representation in Eurasian History, ed. Peter Fibiger Bang and Dariusz Kołodziejczyk (Cambridge: Cambridge University Press, 2012), 171-172, asserts that "imperial eschatology" largely began with Eusebius when he suggested "that Byzantium was Christ's universal and eternal kingdom on earth, that is, the empire was identified with [Daniel's] fifth, extrahistorical empire." Gilbert Dagron, Emperor and Priest: The Imperial Office in Byzantium, trans. Jean Birrell (Cambridge: Cambridge University Press, 2007), 156, and András Kraft, "Byzantine Apocalyptic Literature," in The Cambridge Companion to Apocalyptic Literature, ed. Colin McAllister (Cambridge: Cambridge University Press, 2020), 181, assert that the Byzantines identified their empire with the kingdom of heaven, without specific mention of Eusebius.
} 
eschatology, Eusebius of Caesarea, in no way suggested that the Roman Empire was Daniel's fifth kingdom or the kingdom of heaven.

This is not the first reexamination of Eusebius's eschatological views. Several scholars have raised questions over whether Eusebius really subscribed to a "realized eschatology" or treated Constantine and his sons as eschatological figures. ${ }^{27}$ None of these scholars, however, has attempted to make sense of the problematic line in the Tricennial Oration in which Eusebius seems to equate Constantine's sons with the eschatological inheritors of the eternal fifth kingdom. Nor have they directly addressed several other passages in Eusebius's corpus-most notably in his Life of Constantinewhich also continue to be used to support the mistaken notion of his "realized" or "imperial" eschatology. Perhaps for these reasons, the more nuanced and accurate descriptions of Eusebius's political and eschatological views have not swayed the wider historiography, as indicated in the secondary material cited above. This article, therefore, will confront the common arguments in favor of Eusebius's "realized eschatology" and will argue definitively that Eusebius did not identify the Roman Empire with the eschatological kingdom of heaven, either in the Tricennial Oration or in any of his other writings. It will show that Eusebius evidently held that the Roman Empire was the fourth kingdom of Daniel-a worldly and mortal empire-and repeatedly expressed an expectation that an everlasting eschatological kingdom would dawn only at Christ's second coming.

\section{Eusebius Reassessed}

Most scholarship that presents Eusebius as an advocate of a "realized" or "imperial" eschatology bases this premise on two misapprehensions. The first is that Eusebius served as a spokesman for Constantine and, therefore, had a vested interested in elevating Constantine's reign as the beginning of a transcendent new age. The second is that Eusebius gradually abandoned any expectation of the second coming of Christ or attachment to traditional Christian eschatology and so could plausibly convince himself that Constantine inaugurated a transcendent new age. Both of these assumptions, however, have already been disproved in specialized scholarship on Eusebius.

Especially in the nineteenth and early twentieth centuries, Eusebius was often portrayed as slavishly devoted to Constantine or else as the emperor's cynical propagandist. $^{28}$ This view continues to live on in some scholarly literature. Some recent work

\footnotetext{
${ }^{27}$ Michael Hollerich, "Religion and Politics in the Writings of Eusebius: Reassessing the First "Court Theologian," Church History 59, no. 3 (September 1990): 309-325, and Hollerich, Eusebius of Caesarea's Commentary on Isaiah, 174-203, show that Eusebius, in his Commentary on Isaiah, gave little eschatological importance to either the empire or emperor but instead presented the church and clergy as the fulfillment of biblical prophecy. Hazel Johannessen, The Demonic in the Political Thought of Eusebius of Caesarea (Oxford: Oxford University Press, 2016), 172-173, observes that Eusebius envisioned the world after the conversion of Constantine as full of demons and has pointed out that this contradicts "the widespread idea that Eusebius viewed Constantine as a victorious eschatological figure." Aaron Johnson, Eusebius (New York: I. B. Tauris, 2014), touches on the bishop's eschatological views, stating on page 150: “The oft-repeated modern assertion that Eusebius promoted a 'realized eschatology' . . is misleading. Instead, the bishop maintained a vision of a future eschatological establishment of Christ's kingdom throughout his corpus, even in the Tricennial Oration."

${ }^{28}$ The classic examples of Eusebius portrayed as propagandist are Jacob Burckhardt, The Age of Constantine the Great, trans. Moses Hadas (1853; New York: Pantheon, 1949), 260-283; and Erik Peterson, Der Monotheismus als Politisches Problem: Ein Beitrag zur Geschichte der politischen Theologie
} 
has even suggested that Eusebius's political writings were an extension of a program of Constantine's imperial propaganda that sought to portray the emperor as a new Messiah, perhaps even the triumphant second coming of Christ himself. ${ }^{29}$

Nonetheless, more cautious scholarship on Eusebius in the past several decades has largely dismantled this outdated image of Eusebius as imperial mouthpiece. Already in 1976, Gerhard Ruhbach showed that Eusebius remained foremost a bishop and theologian. ${ }^{30}$ In 1981, Timothy Barnes put to rest the notion that Eusebius was particularly close to Emperor Constantine or in any way acted as an adviser or spokesman: "He [Eusebius] was no courtier, still less a trusted counselor.... He probably met and conversed with the emperor on no more than four occasions." ${ }^{31}$ Rather, Barnes points out, Eusebius was a provincial bishop who mostly worked far from the capital and who wrote for his own purposes. Building on the work of Ruhbach and Barnes, Aaron Johnson has demonstrated that Eusebius was far more concerned with defending the Christian faith and advocating for the church than with glorifying the emperor or the empire.

Indeed, Eusebius displayed a marked ambivalence toward the Roman Empire through much of his literary career. As Aaron Johnson has pointed out, Eusebius conceived of Christians as having an ethnos distinct from the Romans. In Eusebius's two complementary apologetic works, the Preparation for the Gospel (Praeparatio evangelica) and the Proof of the Gospel (Demonstratio evangelica), he treats the Roman Empire as a force of terrible power that historically had played a role similar to the one the Assyrian and Babylonian empires played in the history of the ancient Jews: sometimes bringing God's judgment and sometimes simply acting as an enemy of God's people. ${ }^{32}$ True, by the time he composed the Tricennial Oration and the Life of Constantine, Eusebius had become a supporter of collaboration between Christianity and the Roman state. He certainly had a high opinion of Constantine (and, as we shall see, Augustus). Nonetheless, Eusebius apparently viewed Roman history as a succession of good and bad emperors - replete with high points and low points, but hardly perfect. $^{33}$

The second major premise upon which assertions about Eusebius's "realized" or "imperial" eschatology is based-the position that Eusebius gradually abandoned a belief in the second coming of Christ-has also largely been disproven. In his General Elementary Introduction to the Gospel (the three surviving books of which are often referred to as the Prophetic Selections), Eusebius scoured the Old Testament

im Imperium Romanum (Leipzig: Hegner, 1935), 71-84. Eger, "Kaiser und Kirche," 110-114, responding to these, presented Eusebius as less cynically attached to Constantine, though increasingly devoted to the emperor as time went on.

${ }^{29}$ Pierre Maraval, La théologie politique de l'Empire Chrétien: Louanges du Constantin (Triakontaétérikos) (Paris: Éditions de Cerf, 2001), 65-67; and Jonathan Bardill, Constantine, Divine Emperor of the Christian Golden Age (Cambridge: Cambridge University Press, 2015), 338-384.

${ }^{30}$ Ruhbach, "Die politische Theologie," 236-258. This point has recently been reemphasized in Devin Singh, "Eusebius as Political Theologian: The Legend Continues," Harvard Theological Review 108, no. 1 (January 2015): 129-154.

${ }^{31}$ Timothy D. Barnes, Constantine and Eusebius (Cambridge, Mass.: Harvard University Press, 1981), 266.

${ }^{32}$ Aaron P. Johnson, Ethnicity and Argument in Eusebius' Praeparatio Evangelica (Oxford: Oxford University Press, 2006), 153-197.

${ }^{33}$ See, for example, James Corke-Webster, Eusebius and Empire: Constructing Church and Rome in the Ecclesiastical History (Cambridge: Cambridge University Press, 2019), 249-279. 
for prophecies about Christ's life, death, resurrection, and second coming at the end of time. ${ }^{34}$ In this work, written sometime during the Great Persecution, Eusebius clearly awaited the impending second coming of Christ; all would be judged, and the good would be subsumed into an eternal heavenly kingdom. ${ }^{35}$ Nonetheless, several scholars have explicitly argued that there was a gradual change in Eusebius's views. ${ }^{36}$ D. S. Wallace-Hadrill and Podskalsky, for example, admit that, in his General Elementary Introduction, Eusebius expected the imminent second coming to bring an end to the persecution; yet, they argue that with Constantine's embrace of Christianity, Eusebius abandoned such eschatological expectation. ${ }^{37}$

Frank Thielman, however, has already demonstrated that Eusebius continued to refer often to Christ's second coming in his later works. ${ }^{38}$ For example, in book 6 of his Proof of the Gospel, Eusebius identifies Old Testament prophecies (Habakkuk 3; Isaiah 66:18-19) as predictions of Christ's glorious second coming. ${ }^{39}$ Moreover, though the second half of the Proof of the Gospel is not extant, some of these books apparently dealt directly with the end of the world and the second coming. ${ }^{40}$ Thielman pointed out that even the Tricennial Oration and the Life of Constantine took for granted the transience of the present world and the coming of a future kingdom of God. ${ }^{41}$ Finally, Thielman showed that Eusebius's On the Theophany, composed sometime between 333 and $337 \mathrm{AD}$ (perhaps one of his last compositions and, therefore, potentially useful in providing insight into the bishop's position on eschatology late in life), talks frankly of Christ's second coming. ${ }^{42}$

\footnotetext{
${ }^{34}$ Only books 6-9 of General Elementary Introduction to the Gospel survive. These have been edited by Thomas Gaisford and reprinted in Patrologia cursus completus series graeca [hereafter cited as PG] (Paris: Migne, 1857-1866), 22:1017-1260, under the title Eclogae Propheticae.

${ }^{35}$ On the General Elementary Introduction to the Gospel, including its date, see Johnson, Eusebius, 54-63. According to Barnes, Constantine and Eusebius, 168: "The surviving books of the General Elementary Introduction have an insistent emphasis on Christ's second coming in glory which is far more urgent than in any of Eusebius' other works."

${ }^{36}$ Perhaps the first to argue for a gradual growth in the importance of the empire over time in Eusebius's writings is Eger, "Kaiser und Kirche," 97-115, though Eger deals very little with the issue of eschatology.

${ }^{37}$ Podskalsky, Byzantinische Reichseschatologie, 11, 11n59; and D. S. Wallace-Hadrill, Eusebius of Caesarea, (London: Mowbray, 1960), 177.

${ }^{38}$ Frank S. Thielman, "Another Look at the Eschatology of Eusebius of Caesarea," Vigiliae Christianae 41, no. 3 (January 1987): 226-237.

${ }^{39}$ Eusebius, Proof of the Gospel 6.15, 6.25; and see Thielman, "Another Look," 229-230.

${ }^{40}$ Barnes, Constantine and Eusebius, 182, asserts that the missing books began with Christ's resurrection (where the surviving text breaks off), proceeded through the rest of history, and "included a substantial discussion of the end of the world and of the second coming of the Lord in glory and for judgment."

${ }^{41}$ Thielman, "Another Look," 231-232.

${ }^{42}$ The Greek text of On the Theophany is mostly lost, but it survives in its entirety in a Syriac translation. It was edited and published in Samuel Lee, Eusebius, Bishop of Caesarea, on the Theophania: A Syriac Version, Edited from an Ancient Manuscript Recently Discovered (London: Society for the Publication of Oriental Texts, 1842), and also translated in Samuel Lee, Eusebius Bishop of Caesarea on the Theophania, or Divine Manifestation of Our Lord and Saviour Jesus Christ (Cambridge: Duncan and Malcolm, 1843). Lee, in an extensive introduction and notes in his translation, argued that Eusebius subscribed to a "realized eschatology" (without using that term). Most notably, in 282n1, Lee claimed that since Eusebius mentioned a prophecy in On the Theophany that the world would end when the Gospel had been spread to all the world, and since Eusebius had already emphasized that nations throughout the world had accepted Christianity, "it is evident he believed the End had come." This is hardly convincing, since Eusebius repeatedly refers to the second coming of Christ in the future. In fact, Lee seems to use Eusebius as a mouthpiece for his own views about biblical prophecy.
} 
Subsequently, Michael Hollerich has shown that Eusebius also dwelled at length on the second coming of Christ, the destruction of the current order, and the eternal heavenly kingdom of Christ in his Commentary on Isaiah, probably composed between 325 and $327 \mathrm{AD}^{43}$ As Hollerich notes in his study of the text: "Eusebius has preserved the basic structure of traditional biblical eschatology, in which Christ returns at the end of time to judge all men after a universal resurrection, and to consign them to their respective fates for eternity." 44

Eusebius did break with some of his pre-Constantinian forebears regarding one major facet of eschatology: he fiercely opposed chiliasm (also called "millennialism"), that is, the controversial belief (derived from Revelation 20) that Christ's kingdom would be manifested for one thousand years upon the earth. Chiliasm had been popular in the early church. Eusebius's older contemporary, Lactantius (d. circa 325 AD), for example, assures the readers of his Divine Institutes that Christ, at his second coming, will reign on earth for one thousand years. In this last age, according to Lactantius, the earth will overflow with abundance, the Christian survivors of the last tribulations will procreate together, the surviving pagans will serve as their slaves, and the martyrs will be resurrected to govern alongside Christ. ${ }^{45}$

Eusebius rejected this view of the heavenly kingdom entirely. He was, no doubt, influenced by Origen, who had asserted in his On First Principles (written around $229 \mathrm{AD}$ ) that those who believed that there could be a worldly kingdom under Christ-with eating, drinking, and sex, and with Christians ruling over gentileswere in error: "Such then are the views of those who do indeed believe in Christ, but, in understanding the divine scriptures in a sort of Jewish sense, derive from them nothing worthy of divine promises." 46 Origen argued instead for an allegorical interpretation which aligned more closely with Christ's words in the Gospel of John (18:36): "My kingdom is not of this world."

For Eusebius, who was deeply influenced by the teachings of Origen, the concept of the millennium of Christ ruling on earth trivialized the heavenly kingdom. In his Ecclesiastical History, Eusebius approvingly quotes Origen's student Dionysius of Alexandria (d. 264 $\mathrm{AD}$ ) in his indictment of chiliasm: "It leads them [believers] to hope for small and mortal things in the kingdom of God and for things such as exist now." ${ }^{77}$ Eusebius was outspoken that the eternal kingdom spoken of in Daniel and other prophecies would not be an earthly realm full of "the delights of the belly and of sexual passion," but rather that it would be a heavenly, otherworldly state under Christ's eternal rule after the end of time. This opposition to chiliasm was a recurrent theme in his work. He remained dubious about the canonicity of the Book of Revelation. ${ }^{48}$ One possible motivation for Eusebius's Chronicle was to provide an alternative to the chronicle of Julius Africanus, whose

\footnotetext{
${ }^{43}$ Eusebius's Commentary on Isaiah was edited by Bernard de Montfaucon and reprinted in PG 24:77526. A newer edition has been produced: Eusebius Werke, vol. 9, Der Jesajakommentar, ed. Joseph Ziegler (Berlin: Akademie Verlag, 1975). On the date of Eusebius's Commentary on Isaiah, see Hollerich, Eusebius of Caesarea's Commentary on Isaiah, 19-26.

${ }^{44}$ Hollerich, Eusebius of Caesarea's Commentary on Isaiah, 200.

${ }^{45}$ Lactantius, Divine Institutes, 7.24.1-8.

${ }^{46}$ Origen, On First Principles, 2.11.2. The original Greek text of Origen's On First Principles is lost save for a few fragments, but it has been preserved in the fourth-century Latin translation, Rufinus's De principiis (another, more literal Latin translation by Jerome is mostly lost). Here, I use John Behr, Origen: On First Principles (Oxford: Oxford University Press: 2017), 2:270-271; I have modified Behr's translation.

${ }^{47}$ Eusebius, Ecclesiastical History 7.24.

${ }^{48}$ Eusebius, Ecclesiastical History 3.25.2-4.
} 
chronology was influenced by his chiliasm. ${ }^{49}$ Even in the Commentary on Isaiah, where he describes the reign of Christ together with his saints in the New Jerusalem, Eusebius scrupulously avoids chiliastic sentiments. ${ }^{50}$

There is no indication that Eusebius ever wavered from his anti-chiliasm. This alone makes it unlikely that he could have considered the Roman Empire to be the fifth kingdom of Daniel, since Eusebius did not believe that the kingdom of the Messiah would exist on earth. If there would be no earthly millennium, the fifth kingdom had to be the eternal merging of heaven and earth after the Last Judgment, not the Roman Empire.

\section{Pax Romana and Biblical Prophecy}

Despite Eusebius's clear opposition to chiliasm, numerous scholars have suggested that he actually rejected the idea of the millennium under Christ because he believed that the millennium had already begun-not under Christ, but under Roman rule. For example, in a study of historical varieties of millennial expectation, Richard Landes classifies Eusebius's views as "imperial millennialism." According to the scholar of late antique religion Yuri Stoyanov: "Constantine the Great's imperial apologist, Eusebius of Caesarea, . . . envisage [d] Christ's thousand-year reign on earth to be manifested through the Christian Roman Empire which thus was to merge with the divinely-founded ultimate kingdom of the Danielic schema." 52 Much as Augustine of Hippo would later undermine chiliasm by identifying the millennium from Revelation 20 with the era of the church, Eusebius supposedly could deny a literal millennium while identifying it symbolically with the Roman Empire. In light of Eusebius's doubts about the status of the Book of Revelation, this seems unlikely, but the argument merits exploration and a response. Proponents of this position often cite the Tricennial Oration, but they also point to other works where Eusebius suggests that the Old Testament prophecies about an era of peace had been fulfilled in the Roman Empire. ${ }^{53}$ Erik Peterson first called attention to several of

\footnotetext{
${ }^{49}$ Wallace-Hadrill, Eusebius of Caesarea, 188; and William Adler, "Eusebius' Chronicle and Its Legacy," in Eusebius, Christianity, and Judaism, ed. Harold W. Attridge and Gohei Hata (Detroit, Mich.: Wayne State University Press, 1992), 487. Adler, "Eusebius' Critique of Africanus," in Julius Africanus und die christliche Weltchronik, ed. Martin Wallraff (Berlin: De Gruyter, 2006), 154-155, acknowledges, however, that Eusebius spared Africanus from the accusation of being a chiliast, probably because Africanus's chronology was not in the service of end-time calculations. I am grateful to one of the peer reviewers for this reference.

${ }^{50}$ Pointed out by Hollerich, Eusebius of Caesarea's Commentary on Isaiah, 174, 198.

${ }^{51}$ Richard Landes, Heaven on Earth: The Varieties of the Millennial Experience (Oxford: Oxford University Press, 2011), 22-25.

${ }^{52}$ Yuri Stoyanov, Defenders of the True Cross: The Sasanian Conquest of Jerusalem in 614 and Byzantine Ideology of Anti-Persian Warfare (Vienna: Verlag der Österreichischen Akademie der Wissenschaften, 2011), 59; and Yuri Stoyanov, "Apocalypticizing Warfare: From Political Theology to Imperial Eschatology in Seventh- to Early Eighth-Century Byzantium," in The Armenian Apocalyptic Tradition: A Comparative Perspective, ed. Kevork Bardakjian and Sergio La Porta (Leiden: Brill, 2014), 392-393. The idea that Constantine and his supporters proclaimed the empire the kingdom of the millennium is even more forcefully made by the theologian Jürgen Moltmann in his work The Coming of God: Christian Eschatology, trans. Margaret Kohl (London: SCM Press, 1996), xv: "The Constantinian imperial churches condemned early Christian millenarianism only because they saw themselves in the Christian imperium as 'the holy rule' of Christ's Thousand Years' empire. So every future hope for a different, alternative kingdom of Christ was feared and condemned as heresy." There is absolutely no historical basis for this grand claim.

${ }^{53}$ For example, Moltmann, Coming of God, 161, cites the allusion to the Book of Daniel in the Tricennial Oration.
} 
these lines in his 1935 Monotheism as a Political Problem in order to argue that Eusebius revealed himself as a tactless political propagandist by claiming that eschatological prophecies from the Old Testament had been fulfilled in the Pax Romana. ${ }^{54}$ Some subsequent scholarship has taken this accusation to its logical conclusion. Since such prophecies were usually associated with the Messiah, some have argued that Eusebius therefore presented the Roman Empire actually as the messianic kingdom (and as such, it could represent the thousand-year kingdom from Revelation). A close look at Eusebius's statements in these works, however, will show that this is not the case.

Modern scholars, following Peterson, have made much of the important place the Pax Romana established by Emperor Augustus has in Eusebius's apologetic works. ${ }^{55}$ Eusebius frequently repeats the formulation of his intellectual forebears-most prominently Melito of Sardis and Origen-that Christ's birth during the reign of the first emperor, Augustus, was no coincidence: the unification of the world under Roman rule established the necessary circumstances for the spread of the Gospel. ${ }^{56}$ Eusebius builds upon this concept further by suggesting that Augustus's victory over all his rivals and divergent governments prefigured Christ's triumph over polytheism. ${ }^{57}$ Further, in the Proof of the Gospel, Eusebius reads Micah 4:4-"they shall all sit under their own vines and under their own fig trees, and no one shall make them afraid"-and Isaiah 2:4-"they shall beat their swords into plowshares, and their spears into pruning hooks; nation shall not lift up sword against nation, neither shall they learn war any more"-as prophecies proved true when Augustus brought an end to endemic war in the Mediterranean. ${ }^{58}$ Could such statements indicate that Eusebius preached a realized eschatology, wherein the kingdom of heaven was already manifested in Jesus's day, not in his ministry but in the Roman Empire which enforced the kingdom of peace? ${ }^{59}$

A careful reading of the relevant passages does not bear out such an interpretation. The Proof of the Gospel was an apologetic work, and the clear target of the chapters

\footnotetext{
${ }^{54}$ Peterson, Der Monotheismus, 75-79.

${ }^{55}$ These include Glenn F. Chesnut, The First Christian Histories: Eusebius, Socrates, Sozomen, Theodoret, and Evagrius (Paris: Beauchesne, 1977), 76-78; Francis Oakley, Empty Bottles of Gentilism: Kingship and the Divine in Late Antiquity and the Early Middle Ages (to 1050) (New Haven, Conn.: Yale University Press, 2010), 89-116; Paul Alexander, "The Strength of Empire and Capital as Seen Through Byzantine Eyes," Speculum 37, no. 3 (July 1962): 353-354; and Hervé Inglebert, Les Romains Chrétiens face à l'Historie de Rome: Christianisme et Romanites en Occident dans l'Antiquite tardive (IIIe-Ve siecles) (Paris: Institut d'Études Augustiniennes, 1996), 165-167. Johnson, Ethnicity and Argument, 178, however, rightly points out that in Eusebius's Proof of the Gospel "the historical fact of Augustus' rise to power over other Roman strong men (or even more, over the Hellenistic kingdoms) functions as a proof of Christ's conquering of the warring daemons, and does not render explicit sacralization to the imperial office."

${ }^{56}$ Eusebius, Preparation for the Gospel 1.4.1-5; Eusebius, Proof of the Gospel 3.7.33-35, 6.20; Eusebius, Ecclesiastical History 4.26; and Eusebius, On the Theophany 3.1-2.

${ }^{57}$ Eusebius, Proof of the Gospel 3.7, 7.2; and Eusebius, Oration on the Church of the Holy Sepulcher 16.4. This idea was also reflected visually in the canones, the second book of Eusebius's Chronicle, in which Eusebius organized the historical events into various parallel columns labelled by people or nation (Assyrians, Hebrews, Egyptians, Athenians, and so on); the various columns gradually drop out as peoples disappear or are conquered, so that by the time of Christ's birth there are only columns for the Romans and Hebrews, and then, after the fall of Jerusalem in 70 AD, only for the Romans. In this way, polyarchy and the division of history among various peoples yield, finally, to the Romans and their universal empire.

${ }^{58}$ Eusebius, Proof of the Gospel 8.3 .

${ }^{59}$ This interpretation is suggested by Dvornik, Early Christian and Byzantine Political Philosophy, 2; 616; and Chesnut, First Christian Histories, 160, 168. See also Raffaele Farina, L'impero e l'imperatore cristiano in Eusebio di Cesarea: La prima teologia politica del Cristianesimo (Zurich: PAS, 1966), 143-163.
} 
where Eusebius discusses these prophecies was the Jews. Eusebius attempts to demonstrate that although the Jews rejected Jesus as the Messiah, his birth corresponded to Old Testament prophecies that the Jews already associated with the Messiah:

The Holy Scriptures proclaim that there will be clear signs of the times of the coming of the Messiah.... And that the proofs that those times had come would be the ceasing of the Mosaic worship, the desolation of Jerusalem and of its temple, and, moreover, the subjugation of all the Jewish nation by its foes and enemies. And they also suggest other signs of those times: an abundance of peace, the overturning in nation and city of ancient regional and local forms of government, the rejection of polytheistic and demonic idolatry, and the knowledge of the religion of one God, the creator of all things. ${ }^{60}$

Eusebius argues that all these things had happened: the Jewish Temple and Jerusalem had been destroyed by the Romans only shortly after the time of Jesus, the Jews had been subjugated by their enemies (the Romans), and around the time of the birth of Jesus, Augustus had brought about an abundance of peace and overturned all other governments. Therefore, Eusebius argues: "What is the alternative except that the prophesied king, the Messiah of God, has come." ${ }^{61}$ Many of the prophesied circumstances of the birth of the Messiah had been brought about by Roman imperialism, but this was simply incidental for Eusebius. He was not focused on Roman power; he was trying to prove that Jesus was the Messiah. If anything, Eusebius suggested, the Jews had erred in identifying the prophecies of peace with a powerful earthly kingdom (a Jewish kingdom under the governance of the Messiah); the Jews had overlooked the true Messiah because they failed to realize that the prophecies only meant that the Messiah would be born in a time of peace. The Roman Empire of Augustus laid the groundwork for the first coming of Christ, but it was not a messianic kingdom.

Though Eusebius clearly did not suggest that Augustus inaugurated the heavenly kingdom, several scholars have plausibly suggested that Eusebius treated Constantine as the fulfillment of that which Augustus began. ${ }^{62}$ And, indeed, Eusebius suggests in various works that the end of the persecution of Christianity and imperial support for the faith also fulfilled prophecies of peace. This, too, has often been used to support the argument that Eusebius identified the Roman Empire as the messianic kingdom and, further, that Constantine was a new Messiah. This view was perhaps most effectively articulated by the church historian Robert Markus: "Verses which had traditionally been interpreted in the Church in a messianic sense, are now boldly referred to the person of Constantine. Eusebius introduces his eulogy of Constantine in the last book of the Ecclesiastical History as the messianic 'new song unto the Lord.'... Constantine brings to a fulfilment what God himself had prepared in Christ and Augustus." ${ }^{23}$ As a result, Markus argues: "Eusebius represents Constantine with all the features of a

\footnotetext{
${ }^{60}$ Eusebius, Proof of the Gospel 8.Proem.2-3.

${ }^{61}$ Eusebius, Proof of the Gospel 8.4.1.

${ }^{62}$ For example: Peterson, Der Monotheismus, 83.

${ }^{63}$ R. A. Markus, Saeculum: History and Society in the Theology of St. Augustine (Cambridge: Cambridge University Press, 1970), 49-50. Similarly, Auguste Luneau, L'histoire du salut chez les Pères de l'Église: La doctrine des âges $d u$ monde (Paris: Beauchesne, 1964), 128, recognizes that Eusebius believed in Christ's future second coming but, nonetheless, noted that his fulsome description of Constantine's peaceful reign in the Ecclesiastical History made it seem as if the Parousia had already begun.
} 
Messianic Saviour-king." ${ }^{\prime 64}$ Nonetheless, Markus is very careful to clarify: "Eusebius, naturally, stops short of pressing the implications of this messianic conception to its limits: Constantine is not actually the saviour, nor is his Empire actually the Kingdom of Christ." 65 Some more recent scholarship has not exhibited the same caution. For example, according to Francis Oakley, Eusebius invoked such prophecies to suggest that, with Constantine's reign, "the world might be witnessing at long last the dawning of the messianic era that, as the scriptures had foretold, was destined to succeed the reign of Antichrist." ${ }^{\text {"6 }}$ Richard Landes has similarly claimed that Eusebius hailed Constantine as "the savior who inaugurated the 'peace' the prophets had promised."67

Such statements, however, wrongly imbue the concept of peace with automatic eschatological meaning. True, Eusebius was keen to present the reign of Constantine as the fulfillment of prophecies from Psalms, Isaiah, and Micah-repeating such assertions in his Ecclesiastical History, his Oration on the Holy Sepulcher, and in his Commentary on Isaiah-but it is necessary to approach these claims carefully. Eusebius clearly believed that Constantine played an important role in God's plan for history, a role that the prophets may have foreseen, but just because Constantine brought an end to persecution and civil war did not mean that such a peace was the final cosmic peace, nor did it make him any more of a Messiah than it had Augustus.

Though modern scholars have often focused on the importance of the emperor in Eusebius's writings, the bishop of Caesarea was concerned primarily with Christianity, the church, and the figure whom he actually considered the MessiahJesus Christ. When he cites prophecies of peace in book 10 of his Ecclesiastical History, it is to celebrate the peace and prosperity of the church; Constantine was the facilitator of this, to be sure, but in doing so he was simply a good servant of Christ. Eusebius's Oration on the Holy Sepulcher is particularly instructive on this point. In this oration, which may have been delivered in Constantine's presence, Eusebius cites Psalm 72:8 and Isaiah 2:4 as prophecies fulfilled in the recent peace of the church and follows this with praise for a great king who had inaugurated peace, subdued the power of demons, defeated tyrants, and brought an end to blood sacrifices; this king was not Constantine, it was Jesus Christ. ${ }^{68}$ In his Commentary on Isaiah, Eusebius likewise presents the contemporary peace of the church as the fulfillment of prophecy, but he never even mentions Constantine by name. As Michael Hollerich has pointed out, Eusebius had the opportunity in this commentary to try to associate Constantine with Cyrus the Great-a conquering king and liberator described as God's anointed ( $\tau \hat{\omega} \chi \rho i \sigma \tau \hat{\omega} \mu \mathrm{ov})$ in Isaiah 45 -but he did not do so. ${ }^{69}$ Instead, his focus in the Commentary is on Jesus Christ, Eusebius's actual Messiah and the focus of his devotion.

\footnotetext{
${ }^{64}$ R. A. Markus, “The Roman Empire in Early Christian Historiography," The Downside Review 81, no. 265 (October 1963): 344.

${ }^{65}$ Markus, Saeculum, 50.

${ }^{66}$ Oakley, Empty Bottles of Gentilism, 92. Oakley, notably, suggested that Eusebius only hinted at such ideas inconsistently.

${ }^{67}$ Landes, Heaven on Earth, 24. Moltmann, The Coming of God, 161, likewise claimed that Eusebius and his contemporaries understood the reign of Constantine as follows: "The pax Romana instituted by Augustus and completed by Constantine is the realization of the pax messianica and therefore of the 'Thousand Years' empire."'

${ }^{68}$ Eusebius, Oration on the Holy Sepulcher 16.7-12. Eusebius takes a quite positive view of the Roman Empire in this oration, but Christ's importance is always supreme.

${ }^{69}$ Hollerich, "Religion and Politics," 315; and Hollerich, Eusebius of Caesarea's Commentary on Isaiah, 195.
} 


\section{The Kingdom of Heaven in the Tricennial Oration}

As described above, the most common source cited for the view that Eusebius identified the empire of Constantine with the kingdom of heaven has been the Tricennial Oration. This is where, in praising Constantine, Eusebius suggests that through the elevation of Constantine's sons as his heirs, "He [God] fulfills the predictions of the divine prophets, which ages and ages ago proclaimed that 'the saints of the Most High shall take up the kingdom."'70 As we have seen, in his study of Byzantine eschatology, Gerhard Podskalsky interpreted this to mean that Eusebius identified Constantine's empire with the heavenly and eternal fifth kingdom from the Book of Daniel. ${ }^{71}$ Many other scholars have done the same. D. S. Wallace-Hadrill perhaps first highlighted the importance of the allusion to Daniel 7 in the Tricennial Oration in his classic 1960 study of Eusebius, though he did so simply to support the idea that the bishop of Caesarea viewed Constantine as a part of God's plan that had been prophesied in advance; however, Wallace-Hadrill did briefly venture further to suggest that Eusebius understood Constantine's reign as the culmination of God's plan for history and as "an extension of the Kingdom of Heaven upon earth."72 Subsequent scholarship built on this, and put even greater emphasis on the allusion to Daniel. According to Glenn Chesnut's important study of church historians, Eusebius identified the Roman Empire as "the predicted eschatological Kingdom of Peace. ... Eusebius believed that the successive rulers of the Constantinian dynasty, 'the saints of the Most High' in Daniel's vision of the Four Beasts, were to reign as the eschatological emperors." 73 Stephen Shoemaker, on the basis of the Tricennial Oration, concluded that Eusebius believed that "the Kingdom of God and the Roman Empire had become virtually one."74

Once again, however, a careful reading of Eusebius's body of work does not support this interpretation. In his exegetical writings, where he engaged more directly with the prophecies in the Book of Daniel, Eusebius does not adopt the radical new interpretation of the Danielic kingdoms implied in the Tricennial Oration. Instead, he closely follows the traditional Christian interpretation attested by Irenaeus and Hippolytusnamely, that the Roman Empire was, and at the time of Eusebius's writing remained, the fourth kingdom, doomed to pass away like all kingdoms, and that the fifth kingdom would dawn only with the second coming of Jesus Christ.

Such an interpretation is suggested in book 7 of the Proof of the Gospel. Here, Eusebius notes that Biblical prophecies are cloaked in coded language and never mention the Roman Empire explicitly so as to avoid angering the Roman authorities, since

\footnotetext{
${ }^{70}$ Angelo Mai, Scriptorum veterum nova collectio e vaticanis codicibus, vol. 1 (Rome: Burliaeum, 1825), part 2, 174-175; and in Eusebius Werke, vol. 6, Die Demonstratio Evangelica, ed. Ivar Heikel (Leipzig: Hinrichs, 1913), 494.

${ }^{71}$ Podskalsky, Byzantinische Reichseschatologie, 10-12.

${ }^{72}$ Wallace-Hadrill, Eusebius of Caesarea, 186-189. In this chapter, Wallace-Hadrill also quotes a passage about the end of time from Samuel Lee's translation of On the Theophany, so his understanding may have been influenced by Lee's argument that Eusebius believed that history had already come to an end (see note 42 above).

${ }^{73}$ Chesnut, First Christian Histories, 168-169. Chesnut admits that Eusebius also likely believed that "at the very end, of course, this Kingdom of Peace would change its character completely" and that the Roman Empire would "fight on Satan's side in the battle of Armageddon." Chesnut makes no attempt to reconcile these two conflicting views he ascribes to Eusebius.

${ }^{74}$ Shoemaker, Apocalypse of Empire, 40. Shoemaker notably realizes that Eusebius identified the Roman Empire as the fourth kingdom of Daniel; nonetheless, he echoes earlier scholars' assertions that Eusebius identified the Roman Empire with the kingdom of heaven.
} 
either God or the prophets themselves knew these revelations would circulate widely within the Roman Empire. ${ }^{75}$ Of the prophecies whose true meaning would upset the Roman rulers, Eusebius singles out "especially [those] in the visions of Daniel." ${ }^{\text {76 }}$ If Eusebius believed that the visions of Daniel proclaimed Rome the heavenly fifth kingdom, he would have had no reason to suspect that these visions would upset the Roman authorities. $^{77}$

More explicit indications of Eusebius's eschatology would likely have been found in the later books of the Proof of the Gospel, but only the first ten of its twenty total books survive. Some of these lost books apparently dealt directly with the eschaton. Fortunately, fragments of these are preserved in a catena of excerpts from various Greek church fathers on the Book of Daniel compiled by a certain John the Drungarios in the seventh century. ${ }^{78}$ These confirm that Eusebius adhered to a very traditional understanding of Daniel's four kingdoms.

Citing the lost book 15 of the Proof of the Gospel, John the Drungarios excerpts Eusebius's explanation of Nebuchadnezzar's dream of the statue of four metals from Daniel 2. ${ }^{79}$ Here, Eusebius follows the interpretation of the four kingdoms represented by the four metals in the statue in the same way as generations of Christian exegetes before him: the kingdoms are the Babylonians (or "Assyrians," as he calls them), Persians, Greeks, and Romans. ${ }^{80}$ The stone that smashes the statue represented the eschatological kingdom of God. ${ }^{81}$ Eusebius is clear that this fifth kingdom is not the Roman Empire (the Roman Empire was the fourth kingdom). And, moreover, he states explicitly that the kingdom of God will dawn only after the four kingdoms have passed away. $^{82}$

The Daniel catena of John the Drungarios preserves further relevant fragments from Eusebius in its section on Daniel 7 (Daniel's dream of the four beasts). ${ }^{83}$ These

\footnotetext{
${ }^{75}$ Eusebius, Proof of the Gospel 7.1 (323 a-b), in Heikel, Eusebius Werke, 6:310.

${ }^{76}$ Eusebius, Proof of the Gospel 7.1 (323 a-b), in Heikel, Eusebius Werke, 6:310.

${ }^{77}$ This is noted by Johnson, Ethnicity and Argument, 182-183.

${ }^{78}$ The catena is preserved in Codex Vaticanus Ottobonianus Graecus 452; unfortunately, the only edition and study of this document is the confusing and difficult early nineteenth-century version of Mai, Scriptorum veterum, vol. 1, part 2, 105-221 (note that each part of the volume is paginated separately). On the date and author of the catena, see Michael von Faulhaber, Die Propheten-Catenen nach römischen Handschriften (Freiburg: Herder, 1899), 56-57.

${ }^{79}$ Mai, Scriptorum veterum, vol. 1, part 2, 173-175; these fragments are also provided in Heikel's critical edition of the Proof of the Gospel: Heikel, Eusebius Werke, 6:493-494. Johnson, Ethnicity and Argument, 183-184, provides a useful discussion of this fragment.

${ }^{80}$ Eusebius followed Josephus, Antiquities of the Jews, 10.209-210, in suggesting that the iron nature of the fourth kingdom represented the strength of the Roman Empire. Eusebius also softened the negative connotation of the kingdoms (especially the fourth kingdom) by noting that these are the four empires that conquered the Jews, making them tools of God's judgment.

${ }^{81}$ Mai, Scriptorum veterum, vol. 1, part 2, 174-175; and in Heikel, Eusebius Werke, 6:494. Farina, L'impero e l'imperatore Cristiano, 157, argues that the stone smashing the statue represented the Christianization of the Roman Empire; however, as Johnson, Ethnicity and Argument, 183n161, points out, this interpretation is incorrect and "verges on the disingenuous." It represents the destruction of Rome's empire and all other earthly kingdoms. Johnson, in Ethnicity and Argument, 184, assumes that the stone in the vision is the church, which will triumph over all empires; I see no reason to believe Eusebius understood the stone as anything other than the eschatological kingdom at the end of time.

${ }^{82}$ Mai, Scriptorum veterum, vol. 1, part 2, 174.

${ }^{83}$ These fragments can be found in Mai, Scriptorum veterum, vol. 1, part 2, 204-206, They have been reprinted in PG 24:525-528, and in Heikel, Eusebius Werke, 6: 495-496. Unlike in the case of the fragments
} 
fragments again show that Eusebius believed that Daniel's fifth kingdom-the eternal kingdom of the saints-would arrive only after Christ's second coming. One fragment preserves Eusebius's statement that the vision in Daniel 7 "concerns the Antichrist, and the establishment of the kingdom of our glorious savior." 84 In this same fragment, Eusebius discusses the very "saints of the Most High" whom in his panegyric to Constantine he associated with Constantine and his heirs: "Who are these heirs of God, these co-heirs of Christ? The kingdom of heaven has also been promised to them, a kingdom that will be established after the four kingdoms that were seen by

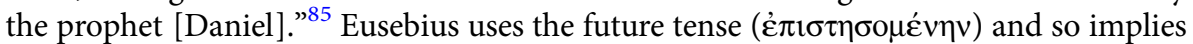
that the history of the four kingdoms has not yet come to an end. The fifth kingdom remained in the future, a kingdom of the saints after the second coming of Christnot the Roman Empire under Constantine. ${ }^{86}$

Although in the fragments on Daniel, Eusebius leaves ambiguous the identity of the "saints of the Most High," in his Commentary on Isaiah he explicitly identifies them: they are the Christian clergy. ${ }^{87}$ At the second coming of Christ, according to Eusebius, the clergy will minister to him and rule over the New Jerusalem. Combining passages from Isaiah 24:23 and 25:1-5, Matthew 25:31-34, and Daniel $7: 18$, Eusebius sets out a vision of the place of the clergy at Christ's right hand in the heavenly kingdom:

Then, the Kingdom of Christ will arise, so that "before his priests he will be glorified." For those whom Christ has honored in the present life with ecclesiastical rank, having made them priests, these same ones he will make worthy of his divinity.... And we will understand how this was an ancient plan if we pay attention to the words of the Savior to those who would be established by his right hand: "Come, you that are blessed by my Father, inherit the kingdom prepared for you from the foundation of the world." ... And our savior and Lord will rule the new age, so that also "all the saints [of the Most High]" "will reign in life," "ruling together" with their Savior. ${ }^{88}$

on Daniel 2, John the Drungarios does not cite the source of these fragments; they may also be from the lost book 15 of the Proof of the Gospel or else from a commentary on the Book of Daniel by Eusebius or his lost Against Porphyry (the pagan philosopher Porphyry had argued that the prophecies in the Book of Daniel were forgeries).

${ }^{84}$ Eusebius, On Daniel, fragment 5 (PG 24:528). This text is also available in Heikel, Eusebius Werke, 6:496. Eusebius here quotes 2 Thessalonians 2:3-5 (concerning the Antichrist) and 1 Thessalonians 4:16 (concerning the second coming) as prophecies that complement Daniel's vision.

${ }^{85}$ Eusebius, On Daniel, fragment 5 (PG 24:528). Also in Heikel, Eusebius Werke, 6:496.

${ }^{86}$ Podskalsky, Byzantinische Reichseschatologie, 35-36, discusses these fragments, and indeed, Podskalsky can only reconcile them with his reading of Eusebius's Tricennial Oration by claiming that when Eusebius spoke of the Roman Empire as the fourth kingdom he meant the pagan empire of the past, whereas Eusebius accepted the Christian empire under Constantine as Daniel's fifth kingdom; however Podskalsky's argument here is contradicted by Eusebius's clear assertion that the fifth kingdom would arrive only after Christ's second coming. Manolis Papoutsakis, Vicarious Kingship: A Theme in Syriac Political Theology in Late Antiquity (Tübingen: Mohr Seibeck, 2017), 46, notes the incongruity between Eusebius's conviction in the fragment that fifth kingdom will come in the future and his supposed assertion in the Tricennial Oration that the Roman Empire is the fifth kingdom, but he does not question the traditional interpretation of Eusebius's eschatological views.

${ }^{87}$ Noted by Hollerich, Eusebius of Caesarea's Commentary on Isaiah, 187.

${ }^{88}$ Eusebius, Commentary on Isaiah 1.84-85, in Ziegler, Eusebius Werke, 9:161. 
Neither Constantine nor his sons nor the Roman Empire are mentioned in this interpretation of the eschatological kingdom. Indeed, in this same passage, Eusebius asserts (referencing 1 Corinthians 15:24) that Christ's kingdom will dawn after God "has destroyed every ruler and every authority and power." 89

The Proof of the Gospel was completed probably around $324 \mathrm{AD}$ and the Commentary on Isaiah was probably written about a decade before the delivery of the Tricennial Oration in $336 \mathrm{AD}$, so it might be argued that Eusebius adopted a new understanding of the meaning of Daniel 7 in the intervening period. But this appears rather unlikely: as we have already seen, Eusebius's understanding of eschatology remained consistent over his body of work. Perhaps more importantly, the notion that Constantine's reign or his elevation of his sons represented the dawning of a heavenly fifth kingdom is contradicted within the Tricennial Oration itself.

Throughout the Tricennial Oration, Eusebius makes it clear that Constantine's empire is emphatically not the eschatological kingdom of heaven from biblical prophecy. Eusebius suggests that the heavenly kingdom does already exist, but it exists within heaven; only at the end of time, with Christ's second coming, will the world be subsumed into the heavenly kingdom. True, Eusebius suggests that Constantine has a unique relationship with the Logos that has enabled him to run his empire on the model of the perfected heavenly kingdom. ${ }^{90}$ However, his empire is precisely that: a mimesis - an earthly reflection-and not the actual heavenly kingdom. In other words, Constantine, as a pious Christian emperor, can govern his realm more like God governs heaven than previous emperors have, but this in no way implies that Constantine's realm is the eternal heavenly kingdom.

Eusebius makes this abundantly clear only two paragraphs after his remark about Constantine's heirs inheriting the kingdom. Here he alludes to a passage in Plato's Republic wherein Socrates has unfavorably contrasted democracy with the rule of a philosopher king, comparing them, respectively, with an untrained crew of a ship and with the ship's captain. In Socrates's metaphor, the untrained sailors (representing the voters of a democracy untrained in rulership) do not know how to steer a ship and, in their ignorance, they cannot comprehend that, when the captain stares at the sky, he is in fact guiding the vessel by practicing the art of navigation (just as a king practices the careful art of rulership). ${ }^{91}$ Eusebius alludes to this metaphor from the Republic apparently because it supports his argument that the perfect order consists of one God in heaven and one emperor on earth. Eusebius builds on Plato's imagery: Constantine as captain gazes at the heavens, according to Eusebius, not to read the stars (as had Plato's captain) but to view the workings of the heavenly kingdom above in order to imitate the divine order administered by God in heaven, so that he might steer the ship of state "according

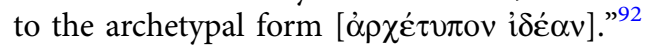

This statement calls to mind another aspect of Platonic philosophy-namely, the world of the forms. For Eusebius, the kingdom of heaven was the ideal form, the perfect

\footnotetext{
${ }^{89}$ Eusebius, Commentary on Isaiah 1.84-85, in Ziegler, Eusebius Werke, 9:161.

${ }^{90}$ In traditional Hellenistic philosophy, the Logos was the force of reason that orders the universe, but Eusebius implied (drawing from the Gospel of John) that it was Christ; therefore, Constantine's piety and embrace of Christianity facilitated his access to this force of cosmic order.

${ }^{91}$ Plato, Republic 6.488d-e.

${ }^{92}$ Eusebius, Tricennial Oration 3.5, in Heikel, Eusebius Werke, 1:204, trans. in Drake, In Praise of Constantine, 87.
} 
archetype, and the empire of Constantine was the earthly form. Constantine, "dressed in the image [ $\epsilon$ iKóvi] of the kingdom of heaven," and governed as much as possible like God governed his kingdom. ${ }^{93}$ Therefore, the Roman Empire had become just and wellgoverned under his rule, but it remained a dim earthly reflection of the heavenly kingdom. Eusebius explicitly contrasts the two by asserting that Constantine eagerly awaits the true kingdom of heaven: "He cherishes in his heart an indescribable longing for the lights there, by comparison with which he judges the honors of his present life to be no more than darkness. For he recognizes that rule over men is a small and fleeting authority over a mortal and temporary life, not much greater than the rule exercised by goatherds or shepherds or cowherds." 94 The Roman Empire, compared to God's heavenly kingdom, is but an unremarkable flock of beasts.

Clearly, Eusebius did not attempt to argue in his Tricennial Oration that Constantine's empire or the accession of his sons represented the kingdom of heaven. There remains, however, an unresolved question: Why exactly did Eusebius suggest, albeit in one isolated passage, that Constantine and his sons fulfilled a prophecy from Daniel 7? Before offering an explanation, it will be useful to examine relevant evidence from a final source which modern scholars have used to try to argue that Eusebius identified the Roman Empire as the heavenly kingdom-namely, Eusebius's Life of Constantine.

\section{The Life of Constantine and Considerations of Rhetoric}

The Life of Constantine, written after the emperor's death, was part panegyric, part hagiography, and part mirror for princes (probably directed at Constantine's sons). ${ }^{95}$ If Eusebius intended to present the reign of Constantine or the inheritance of his sons as the kingdom of heaven on earth, this encomium would be as ideal a setting as any to do so. Eusebius did not explicitly do so, though several scholars have pointed to places in the Life of Constantine where Eusebius seems to have portrayed Constantine's regime as the fulfillment of eschatological prophecy. Paula Fredriksen has summarized the traditional interpretation of Eusebius's eschatology in light of such charged statements in the Life of Constantine thus: "See, Eusebius could say, the prophets spoke not about the end of time, but about our time, now; and the glorious ruler whom they foresaw was not the Christ of the Apocalypse, but our patron, the emperor of Rome." 96

Three examples are often cited to support this interpretation. In the Life of Constantine, Eusebius provides an ekphrasis of a painting Constantine had commissioned for the entrance of his palace (presumably at Constantinople) in which he and his sons, surmounted by "the savior's sign" (either the cross or labarum), trampled an impaled serpent. According to Eusebius, by portraying himself crushing a serpent,

\footnotetext{
${ }^{93}$ Eusebius, Tricennial Oration 3.5, in Heikel, Eusebius Werke, 1:204, trans. in Drake, In Praise of Constantine, 87.

${ }^{94}$ Eusebius, Tricennial Oration 5.5, trans. in Drake, In Praise of Constantine, 90.

${ }^{95}$ Averil Cameron, "Form and Meaning: The Vita Constantini and the Vita Antonii," in Greek Biography and Panegyric in Late Antiquity, ed. Tomas Hägg and Philip Rousseau (Berkeley: University of California Press, 2000), 72-88, situates the Life of Constantine as a mirror for princes.

${ }^{96}$ Paula Fredriksen, Augustine and the Jews: A Christian Defense of Jews and Judaism (New Haven, Conn.: Yale University Press, 2010), 342-343.
} 
which represented the devil (and likely also his vanquished imperial rival Licinius), Constantine wisely alluded to the prophecy in Isaiah 27:1: "On that day the Lord with his cruel and great and strong sword will punish Leviathan the fleeing serpent."97 The historian Charles Odahl has argued that Constantine deployed such imagery purposely to suggest that his reign marked the beginning of Christ's millennial kingdom on earth (so that the slaying of the serpent alluded not just to Isaiah but also to the victory of the Messiah over the dragon, Satan, in the Book of Revelation). ${ }^{98}$ Odahl proposes that Eusebius disseminated Constantine's propagandistic millennialist message to his audience by describing the painting. ${ }^{99}$

In another scene, Eusebius describes the celebrations of Constantine's twentieth regnal year, when he and other bishops were invited to the palace to feast with the emperor and his court; describing the lavishness of the banquet and the respect given to Christian bishops, Eusebius states: "It might have been supposed that it was an imaginary representation [ $\epsilon$ ikóv $\alpha$ ] of the kingdom of Christ." 100 The connection between a feast and the kingdom of God perhaps drew on biblical imagery: Isaiah 25:6-10 describes an eschatological banquet that God will make for all people, and the Gospel of Matthew $(8: 11,22: 1-14,25: 1-13)$ often describes the kingdom of heaven in terms of feasting. Eusebius's statement has been interpreted by several modern scholars as a suggestion that Constantine's feast represented the prophesied "messianic banquet," and therefore, Constantine's rule, more broadly, had manifested the eschatological kingdom of God on earth. ${ }^{101}$

Finally and most notably, Eusebius describes Constantine's renovation of Jerusalem, especially his construction of the great basilica at the site of the holy sepulcher, and

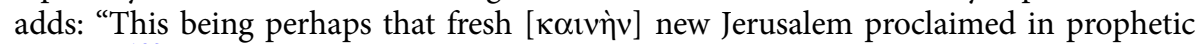
oracles." 102 The reference to the "fresh new Jerusalem" has been taken by some modern scholars to mean that Eusebius intended to indicate that the new Jerusalem foreseen in the books of Isaiah, Ezekiel, and Revelation had been made to descend upon the earth by Constantine. ${ }^{103}$ Jonathan Bardill has summed up this interpretation: "Eusebius'

\footnotetext{
${ }^{97}$ Eusebius, Life of Constantine 3.3. A similar image survives on bronze coins produced by Constantine for the year 327. On these coins, see Patrick Bruun, "The Christian Signs on the Coins of Constantine," Arctos 3, no. 1 (January 1962): 21-23.

${ }^{98}$ Charles Odahl, "The Use of Apocalyptic Imagery in Constantine's Christian Propaganda," Centerpoint 4, no. 15 (Fall 1981): 9-20. On page 15, Odahl nonetheless notes: "It may be doubted that many Christians actually thought the reign of Christ had begun with Constantine's victory over Licinius." See also Chesnut, First Christian Histories, 161-162.

${ }^{99}$ Odahl, "Use of Apocalyptic Imagery," 13. Likewise, Bardill, Constantine, Divine Emperor, 362, suggests that Eusebius described the painting in light of the fact that "Eusebius was prepared to interpret [Constantine's victory over Licinius] as the fulfilment of the prediction in Revelation [about the millennium]." This seems highly unlikely considering Eusebius's skeptical position toward the Book of Revelation. The Book of Revelation, of course, draws heavily from Isaiah, and so, while Eusebius made frequent use of prophecies from Isaiah, modern scholars often mistake these for allusions to Revelation and so interpret his statements in an overly apocalyptic light.

${ }^{100}$ Eusebius, Life of Constantine 3.15. Translation from Averil Cameron and Stuart G. Hall, trans., Eusebius: Life of Constantine (Oxford: Clarendon, 1999), 127.

${ }^{101} \mathrm{See}$, for example, Oakley, Empty Bottles of Gentilism, 92; and Bardill, Constantine, Divine Emperor, 356.

${ }^{102}$ Eusebius, Life of Constantine 3.33. Translation from Cameron and Hall, Eusebius: Life of Constantine, 135.

${ }^{103}$ See, for example, Chesnut, First Christian Histories, 161; and Odahl, "Use of Apocalyptic Imagery," 15.
} 
suggestion that the church might be the long prophesied New Temple carries the striking implication that Constantine, as the founder, might be Christ Himself, who was due to found the New Jerusalem at the time of His Second Coming." ${ }^{104}$

Such characterizations, however, once again read too much into a few isolated comments in order to ascribe to Eusebius a realized eschatology in which the kingdom of heaven had arrived in Constantine's rule. As in the case of the Tricennial Oration, there are passages in the Life of Constantine that contradict the notion that Eusebius tried to depict Constantine as an eschatological figure who had inaugurated the New Jerusalem. Eusebius recounts that, during a ceremony dedicating the new basilica at the Holy Sepulcher, a bishop, in "excessive boldness" called Constantine blessed and told him that he would rule alongside the Son of God in the next life. Eusebius reports that Constantine was annoyed by this excessive praise and responded by saying that he only hoped to be judged worthy as God's slave in both this world and the next. ${ }^{105}$ Eusebius apparently wanted to depict Constantine as both mindful of the difference between the present world and the kingdom to come and humbly aware of his role as a mere servant of God.

Moreover, an eschatological interpretation of Eusebius's praise of Constantine in the Life of Constantine does not accord with Eusebius's views stated in his other works. There is no reason to believe, for example, that his description of the painting of the trampled serpent was designed to invoke an eschatological message. ${ }^{106}$ In his Commentary on Isaiah, Eusebius described Isaiah 27:1 as a prophecy of the end of the world when God/Christ would slay Satan-which is to say that Eusebius interpreted the prophecy as an event that would come to pass in the eschatological future. ${ }^{107}$ Nor did Eusebius, in the Commentary on Isaiah, associate the messianic feast in Isaiah 25 with Constantine: to Eusebius, the feast represented the coming together of all people in the church. ${ }^{108}$ When, in the Life of Constantine, Eusebius describes Constantine's vicennalia celebration as the "Eikóv $\alpha$ of the kingdom of Christ," the idea here is more or less the same as in the Tricennial Oration, where Eusebius describes Constantine's regime as an €ikóv $\alpha$ of the kingdom of heaven (see section IV above). Since Constantine had been a good ruler, in Eusebius's estimation, he was an image (or representation or form) of God's perfect rule in heaven. The feast with Constantine, therefore, was an earthly reflection of the glory that the elect would experience in the kingdom of heaven. Nonetheless, in Eusebius's view, the Roman Empire was not the kingdom of heaven and Constantine emphatically was not the second coming of Christ. This is not to deny that Eusebius drew parallels between Constantine and Christ; however, Eusebius emphasized parallels between Constantine and many biblical figures-most frequently Moses. ${ }^{109}$

Eusebius's statement that Constantine had perhaps built the New Jerusalem foretold by the prophets is more cryptic, but once again, statements in Eusebius's other writings preclude the possibility that he literally meant that Constantine had brought into being the heavenly Jerusalem. If he truly believed this, why did he not once mention it in is his

\footnotetext{
${ }^{104}$ Bardill, Constantine, Divine Emperor, 357.

${ }^{105}$ Eusebius, Life of Constantine 4.48 .

${ }^{106}$ See Hollerich, "Religion and Politics," 317n35.

${ }^{107}$ Eusebius, Commentary on Isaiah 1.89, in Ziegler, Eusebius Werke, 9:172-174.

${ }^{108}$ Eusebius, Commentary on Isaiah, 1.82, in Ziegler, Eusebius Werke, 9:161.

${ }^{109}$ Barnes, Constantine and Eusebius, 271-272; and Michael Hollerich, "The Comparison of Moses and Constantine in Eusebius of Caesarea's Life of Constantine," Studia Patristica 19 (1989): 80-95.
} 
Oration on the Holy Sepulcher, which surely would have been a fitting occasion? In his Commentary on Isaiah, Eusebius suggests that the New Jerusalem will appear after the second coming of Christ (which had clearly not yet taken place) and that it will be the abode of the resurrected saints. ${ }^{110}$ Insofar as the New Jerusalem had already become manifest on earth, it was the church, for the church was the City of God and the True Jerusalem (as opposed to the Jewish city destroyed by the Romans). ${ }^{111}$ Once again, though Eusebius's statement in the Life of Constantine is ambiguous, when viewed in light of Eusebius's overall portrait of Constantine in the entirety of the work and in the context of the bishop's other writings, the interpretations of eschatological maximalists appear extremely unlikely.

One may, perhaps, object to this formulation and argue that Eusebius's isolated aberrant statements about fulfilled prophecy in the Tricennial Oration and Life of Constantine should be given more weight rather than less, since they seem so strongly to contradict traditional Christian eschatology. One might argue that in these places Eusebius let slip his true opinions or put forth a careful trial balloon for a more expansive Christian understanding of the Roman Empire. Nonetheless, the rhetorical context of these works must be considered. The Life of Constantine was, to an extent, a panegyric like the Tricennial Oration, and a panegyric is foremost a context in which to praise, not to pursue a coherent thesis on political theology. ${ }^{112}$

Other surviving panegyrics by non-Christians written in honor of the same emperor are filled with elaborate, religiously inflected praise. Why is it assumed that Eusebius intended his statement that Constantine had perhaps built the New Jerusalem to be taken any more literally than the anonymous, pagan Latin panegyrist intended his suggestion that Constantine might reign like a god over the return of the golden age prophesied in Virgil's Fourth Eclogue $?^{113}$ Did Eusebius believe his claim that Constantine's sons fulfilled Daniel's prophecy about the kingdom of the saints any more than other pagan panegyrists truly believed it when they promised and prayed that Constantine and his sons would rule the earth for all eternity? ${ }^{114}$ It may seem distasteful for a Christian theologian to flatter a ruler in similar terms and to invoke holy scripture as lightly as others invoked Virgil, but in praising Constantine, Eusebius had to pioneer the Christianization of a genre that had long modeled fulsome praise of emperors with reference to gods and ancient prophecies and which played on associative echoes between rulers and classical literature. He may at times have gone rather far. Nonetheless, incautious flattery makes far better sense than the notion that Eusebius had attempted, in a few isolated allusions, to promulgate a wholly new understanding of Christian eschatology.

A useful comparison to Eusebius's rhetoric in his Constantinian texts is provided by an earlier panegyric he composed-one directed not at an emperor or the empire but at

\footnotetext{
${ }^{110}$ See, for example, Eusebius, Commentary on Isaiah 2.2; in Ziegler, Eusebius Werke, 9: 208-209.

${ }^{111}$ See Hollerich, Eusebius of Caesarea's Commentary on Isaiah, 175-178.

${ }^{112}$ As Hollerich, "Religion and Politics," 314, has already suggested: "The sacralized imperialism in [the Tricennial Oration and the Life of Constantine] owes much to rhetorical convention and is an insufficient basis for a comprehensive statement of Eusebius's views on church and empire."

${ }^{113}$ Panegyrici Latini 6.21.5, in XII Panegyrici Latini, ed. R. A. B. Mynors (Oxford: Clarendon, 1964), 202. On this, see Christopher Chinn, "The Reception of Classical Pastoral in the Age of Constantine," in The Life and Legacy of Constantine: Traditions Through the Ages, ed. M. Shane Bjornlie (New York: Routledge, 2017), 34-38.

${ }^{114}$ Panegyrici Latini 7.2.2-5, in XII Panegyrici Latini, Mynors, 205; and Panegyrici Latini 12.26.1-5, in XII Panegyrici Latini, Mynors, 289-290.
} 
a bishop and a church. In his Ecclesiastical History, Eusebius preserved the text of a panegyric he had delivered around the year $316 \mathrm{AD}$ celebrating the construction of a new cathedral in Tyre. In it he praises the building and Paulinus, the bishop who oversaw its construction. Eusebius describes Paulinus much like he would later describe Constantine in the Tricennial Oration: Paulinus's gaze is fixed on heaven in order to imitate its example-in Paulinus's case, so that he might build his cathedral according to the heavenly archetype. ${ }^{115}$ Having compared Paulinus-as builder of the cathedral-

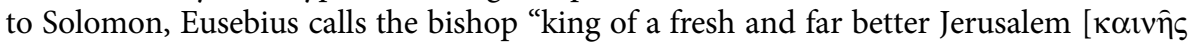

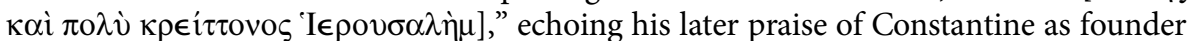

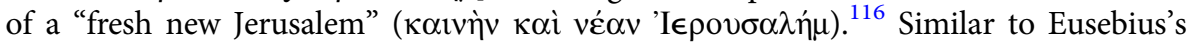
later claim that God "fulfilled the predictions of the divine prophets" ( $\theta \in i \omega v$ $\pi \rho \circ \varphi \eta \tau \hat{\omega} \nu \dot{\alpha} \pi \circ \pi \lambda \eta \rho \circ \hat{i} \theta \epsilon \sigma \pi i \sigma \mu \alpha \tau \alpha)$ through Constantine's raising up of his heirs, in his panegyric for Paulinus, Eusebius asserts that through the bishop and his magnificent decoration of his cathedral God was "fulfilling the prophecy" ( $\alpha \pi \circ \pi \lambda \eta \rho \circ \hat{v} v$ $\pi \rho о \varphi \eta \tau \epsilon i \alpha v)$ of Isaiah (54:11-14) which describes the rebuilding of Jerusalem in jewels and precious stones-an unmistakable reference to the heavenly Jerusalem. ${ }^{117}$ Eusebius's panegyric reaches its crescendo when he suggests that "the entire Christ him-

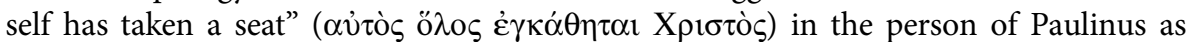
head of the congregation. ${ }^{118}$ One might postulate that Eusebius held the bishop Paulinus as an eschatological Messiah-figure and then transferred this hope onto Constantine, but certainly a much more likely explanation is that the similarity of Eusebius's praise of Paulinus and of Constantine derive from stock features of his laudatory rhetoric.

This is not to say that Eusebius's flattery was necessarily empty or mendacious. Christine Smith has explored Eusebius's use of rhetoric in the panegyric on Paulinus and his cathedral, showing that Eusebius combed the Bible for references to architecture-such as descriptions of the heavenly Jerusalem-and then related these back to the cathedral and its bishop. ${ }^{119}$ As Smith notes, these are allegories and metaphors and are intended not to be literal but evocative. ${ }^{120}$ They might also be understood as typological. ${ }^{121}$ The building of a magnificent church not long after the difficulties of the Great Persecution was the typological precursor to the building of heavenly Jerusalem after the tribulations at the end of time. God was fulfilling Biblical prophecy in a small way through Paulinus, but the fuller and truer fulfillment of the prophecy could be understood as awaiting the end of history. ${ }^{122}$ The function of this was to

\footnotetext{
${ }^{115}$ Eusebius, Ecclesiastical History 10.4.25. The panegyric is edited in Eduard Schwartz, ed., Eusebius Werke, vol. 2, Die Kirchengeschichte, part 2, Die Bücher V bis X (Leipzig: Hinrichs, 1909), 862-883.

${ }^{116}$ Eusebius, Ecclesiastical History 10.4.3.

${ }^{117}$ Eusebius, Ecclesiastical History 10.4.62.

${ }^{118}$ Eusebius, Ecclesiastical History 10.4.67.

${ }^{119}$ Christine Smith, “Christian Rhetoric in Eusebius' Panegyric at Tyre," Vigiliae Christianae 43, no. 3 (January 1989): 226-247.

${ }^{120}$ Smith, "Christian Rhetoric," 236.

${ }^{121}$ This idea has already been considered in Jeremy M. Schott, "Eusebius' Panegyric on the Building of Churches (HE 10.4.2-72): Aesthetics and the Politics of Christian Architecture," in Reconsidering Eusebius: Collected Papers on Literary, Historical, and Theological Issues, ed. Sabrina Inowlocki and Claudio Zamagni (Leiden: Brill, 2011), 186: "Eusebius sees the reconstruction of the church as a typological fulfillment of the construction of the Second Temple."

${ }^{122}$ This appears even more likely considering that at the end of the panegyric (10.4.69-70) Eusebius reminded his audience that the church Paulinus built on earth was but a pale reflection of the
} 
suggest the historical importance of the subject of the panegyric, while also demonstrating Eusebius's authorial skill in identifying parallels between his subject and scripture.

We might understand Eusebius as doing something similar with Constantine in the Life of Constantine: making a skillful display of associative echoes between Constantine's biography and scripture, especially from the Book of Isaiah. ${ }^{123}$ Constantine portrayed himself trampling a serpent just as God kills the serpent in Isaiah 27. Constantine held a grand banquet, reminiscent of the feast of God in Isaiah 25. Constantine rebuilt Jerusalem, and the later books of Isaiah spoke of a New Jerusalem. Constantine's building in Jerusalem was no more the literal fulfillment of the prophecy of the heavenly Jerusalem than had been the church in Tyre, but it was evocative of scripture in the same way, glorifying the first Christian emperor and presenting him perhaps as a step toward-or a foretaste of-the fulfillment of God's promises, but not the ultimate fulfillment of those prophecies.

Such logic can also help explain the meaning of Eusebius's statement in the Tricennial Oration that relates the sons of Constantine to the saints who will inherit the Danielic fifth kingdom. Eusebius likely wanted his audience to notice the similarity between Constantine raising up his heirs and the prophecy in Daniel 7 and, perhaps, to see the ostensible fulfilment of the prophecy in Constantine's sons as an indication of their holiness, since it foreshadowed the truer, fuller fulfillment of Daniel's prophecy at the end of time. In praising Constantine in both the Tricennial Oration and the Life of Constantine, Eusebius suggested that Constantine's reign echoed or rhymed with lines from scripture (just as his life echoed the life of Moses) and pointed toward the future fulfillment of eschatological prophecy, though those prophecies would be truly fulfilled only at Christ's second coming.

In the end, Eusebius's seemingly eschatological statements about Constantine in the Tricennial Oration and Life of Constantine should be understood in the context of rhetorical praise which drew on typological parallels with scriptural prophecies. Such a reading is fully consistent with Eusebius's views on eschatology expressed in his exegetical and apologetic writings. Therefore, this reading should be preferred to the notion that he was proclaiming the Roman Empire as the kingdom of heaven, an idea inconsistent with both his other writings and, more importantly, with other statements found even within the Tricennial Oration and Life of Constantine, both of which at points stress Constantine's humility and the smallness of the Roman Empire in comparison to the kingdom of God.

\section{The Legacy of Eusebius, Past and Present}

Admittedly, this more nuanced understanding of Eusebius's allusions to eschatological prophecy in his panegyrics does not disprove the notion that Eusebius should be characterized as the beginning of Byzantine imperial eschatology. Just as modern readers have misinterpreted Eusebius's eschatological views, his premodern audiences may have done the same. Therefore, more important than what Eusebius may have personally believed is the possible effect of his rhetoric on his audience. Did the Tricennial Oration lead Constantine or his sons to believe that they reigned over Daniel's fifth kingdom? Did

Jerusalem above, stressing the ultimate primacy of the heavenly over the earthly. It should be recalled that Eusebius made a similar point in both the Tricennial Oration and Life of Constantine.

${ }^{123}$ Eusebius's frequent parallels between Constantine and lines from Isaiah become even more understandable when one considers that Eusebius probably completed his Commentary on Isaiah in $326 \mathrm{AD}$, the same year he had one of his few major interactions with Constantine, during the emperor's vicennalia celebrations. Eusebius's mind was likely deeply preoccupied with Isaiah during his exposure to the emperor. 
later readers of the Life of Constantine believe that the heavenly Jerusalem had appeared upon the earth in the time of Constantine? Did Eusebius inspire successive generations of Byzantines to view the empire as the kingdom of heaven on earth?

None of these questions can be answered in the affirmative. Though we have little information about how Eusebius's Constantinian panegyrics were received-either in his lifetime or later-there is no good reason to suppose their influence on late Roman and Byzantine eschatology was significant. Indeed, although several of Eusebius's works proved quite popular and influential, especially his Ecclesiastical History - "as well preserved as any book from antiquity," in the words of its modern editor-his Tricennial Oration and Life of Constantine appear not to have been wellknown through the millennium of Byzantine history. ${ }^{124}$ According to Anthony Kaldellis: "Eusebios' Constantinian writings were not popular in Byzantium." "25 To the extent that the Tricennial Oration and Life of Constantine were read and copied, there is no indication that this activity was driven by any interest in Eusebius's few short allusions to eschatological prophecies. Rather, these works were likely read as rhetorical exemplars and/or as historical documents relevant to the history of the church under the first Christian emperor. ${ }^{126}$ Nor were the eschatological allusions in them excerpted in the way that, for example, a prophecy from the seventh-century history of Theophylact Simocatta was sometimes copied by itself and analyzed for its eschatological meaning in surviving manuscripts of Greek apocalyptic material. ${ }^{127}$ In fact, there is no indication that later Byzantine authors recognized any significance in Eusebius's allusions to the kingdoms of Daniel or the heavenly Jerusalem, and certainly no one appears to have built an eschatological justification of empire upon them. ${ }^{128}$

\footnotetext{
${ }^{124}$ Quotation from Eduard Schwartz, Eusebius Werke, vol. 2, Die Kirchengeschichte, part 3, Einleitungen, Übersichten, und Register (Leipzig: Hinrichs, 1909), cxliv. On the Greek manuscript tradition of Eusebius's Ecclesiastical History, see Matthieu Cassin, "Tradition manuscrite grecque de l'Histoire ecclésiastique," in Eusèbe de Césarée: Histoire Ecclésiastique, ed. Sébastien Morlet and Lorenzo Perrone (Paris: Éditions du Cerf, 2012), 1:209-242. The forthcoming study, Michael J. Hollerich, Making Christian History: Eusebius of Caesarea and his Readers (Oakland: University of California Press, 2021), will no doubt shed much new light on the reception of the Ecclesiastical History.

${ }^{125}$ Kaldellis, Byzantine Republic, 177.

${ }^{126}$ The Tricennial Oration and the Life of Constantine are often found together in manuscripts, along with Eusebius's Greek translation of Constantine's Oration to the Assembly of the Saints and, occasionally, other works by Eusebius, most frequently his Ecclesiastical History. To the extent that the works of other authors are included in these manuscripts, they are most frequently other church histories.

${ }^{127}$ The prophetic excerpt from Theophylact's history is included, with a short commentary, in the following manuscripts: Codex Haunensis Graecus 2147, fols. 12r-13r; Codex Vindobonensis Supplementum Graecum 172, fols. 39v-40v; and Codex Vindobonensis Theologici Graeci 203, fols. 306v-307v. For the reception of the prophecy in late Byzantine history, see Ihor Ševčenko, "The Decline of Byzantium Seen Through the Eyes of Its Intellectuals," Dumbarton Oaks Papers 15 (1961): 183.

${ }^{128}$ In claiming that Eusebius's eschatological statements had a lasting legacy, Magdalino, "History of the Future," 10-11, among others, suggest that Eusebius's allusion to the kingdoms of Daniel in the Tricennial Oration influenced Cosmas Indicopleustes, a "Nestorian" monk who wrote from Egypt in the reign of Justinian, because in his Christian Topography 2.74, Cosmas actually identified the Roman Empire as Daniel's fifth kingdom. Cosmas's interpretation of Daniel deserves to be revisited in a study of its own, but in brief, it can be said that there is no connection-direct or indirect-between Eusebius and Cosmas. In fact, though he wrote in Greek, Cosmas was the protégé of the catholicos of the Syriac Church of the East, Aba I (r. 540-552), and his interpretation of Daniel shows the heavy influence of Syriac Daniel commentaries; see Maurice Casey, "The Fourth Kingdom in Cosmas Indicopleustes and the Syrian Tradition," Rivista di storia e letteratura religiosa 25, no. 3 (1989): 385-403. Moreover, even Cosmas asserted that the Roman Empire would last only up to the completion of history ( $\mu \varepsilon \dot{x} \rho \mathbf{\tau i} \bar{s}$
} 
The fascination with Eusebius's Constantinian panegyrics is a modern phenomenon, and it was modern scholars who first called attention to the eschatological allusions in them in order to attribute to Eusebius a "realized" or "imperial" eschatology. This impulse was based on an outdated understanding of the bishop of Caesarea as either a cynical propagandist for Constantine or a credulous consumer of such propaganda (or both). Moreover, it grew out of a modern discomfort with Eusebius, who seemed too willing to allow the state to co-opt Christianity for its own ends, and out of a tendency to use him as a cautionary symbol. This took on added urgency in the important work on Eusebius and his eschatology produced in the 1930s and after by scholars deeply affected by National Socialism and its co-optation of Christianity. As we have seen, Erik Peterson's influential Monotheism as a Political Problem helped establish the prevailing view of Eusebius's eschatology by disapprovingly suggesting that Eusebius acclaimed Constantine as the fulfillment of messianic prophecy; published in 1935 while the author was in self-imposed exile from Germany following the rise of Hitler's regime, Peterson's study subtly cast Eusebius as representative of a stateand ruler-centric perversion of Christianity that the Nazis were reviving. ${ }^{129}$ During and after World War II, several scholars saw in Constantinian Christianity-embodied by Eusebius-a prototype of the intellectual currents that made possible the worship of the state and its leader under fascist regimes. ${ }^{130}$ Then, in the context of the Cold War, the Byzantine legacy (and sometimes Eusebius himself) was commonly invoked to explain why Russia-the so-called Third Rome-and its Eastern European satellites tended toward absolutism. ${ }^{131}$ Moreover, the Byzantine co-optation of Christian eschatology provided a supposed parallel to how the Soviet Union turned Marx's utopian

$\sigma \cup v \tau \varepsilon \lambda \varepsilon i \alpha \varsigma)$, and he distinguished it from the coming "Kingdom of Christ the Lord" ( $\beta \alpha \sigma i \lambda \varepsilon i \alpha$ tov

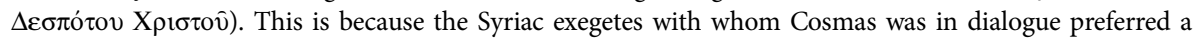
preterist interpretation of Daniel's prophecies (that is, that the prophecies were fulfilled and did not refer to eschatological events) and so identified Daniel's fifth kingdom as the Jewish Maccabean kingdom. Cosmas accepted these basic premises, but he suggested that the Roman Empire should be considered the fifth kingdom instead of the Jewish kingdom that the Romans destroyed.

${ }^{129}$ Peterson, Der Monotheismus, 71-84. Peterson was writing in response to his former colleague, the Catholic Nazi jurist Carl Schmitt and his Politische Theologie: Vier Kapitel zur Lehre von der Souveränität (Munich: Duncker \& Humblot, 1922). Schmitt responded thirty-five years later in his, Politische Theologie II: Die Legende von der Erledigung jeder politischen Theologie (Munich: Duncker and Humblot, 1970), where the barely repentant former Nazi often defended (and, indeed, personally identified with) Eusebius. The Peterson-Schmitt debate has had a major impact on Eusebian scholarship.

${ }^{130}$ See, for example, Hendrik Berkhof, who studied briefly in Berlin under Hans-Georg Opitz (before running afoul of the Gestapo due to his involvement with the underground "Confessing Church," which rejected state control), completed a dissertation on Eusebius's theology, and then, while in hiding from the German occupiers in his native Holland, wrote De Kerk en de Keizer: Een studie over het ontstaan van de Byzantinistische en de theocratische staatsgedachte in de vierde eeuw (Amsterdam: Holland, 1946), which sought to explain the different relationship between church and state in Eastern and Western Europe through the stances of fourth-century theologians. Berkhof cast the central place Eusebius supposedly gave Constantine in the history of salvation as characteristic of Eastern thought, while Athanasius, with his eschatological denunciation of Constantius II as the Antichrist, became a prototype for Western thought (a view influenced by Opitz, the editor of Athanasius's corpus and another contributor to Eusebian scholarship, as cited above in note 16). Berkhof's study was quickly translated into German and proved influential, including on Jürgen Moltmann (whose work is cited above in notes 52, 53, and 67), another figure deeply affected by his experience with the church under the Third Reich.

${ }^{131}$ See, for example, Cyril Toumanoff, "Moscow the Third Rome: Genesis and Significance of a Politico-Religious Idea," Catholic Historical Review 40, no. 4 (January 1955): 411-447. On the (mis)use of the concept of Moscow as the Third Rome through the Cold War, see Donald Ostrowski, "Moscow 
vision of communism into the ideology of a totalitarian state. ${ }^{132}$ Podskalsky, whose juxtaposition of "Christian" and "Byzantine" eschatology was discussed at the beginning of this study, was strongly influenced by both Peterson's treatment of Eusebius and by the tendency to draw parallels between Byzantine and Soviet thought; Podskalsky introduced the idea that the traditional treatment of Eusebius could be applied to all Byzantine eschatology. ${ }^{133}$

Moreover, much of the scholarship that has attributed to Eusebius a "realized eschatology" has done so in the context of contrasting the bishop of Caesarea with Augustine of Hippo. ${ }^{134}$ Some scholarship has used the two theologians as indicative of a divergence between West and East: Augustine's Latin City of God, with its doctrine of the heavenly and earthly cities, supposedly led the West toward separation of church and state, while Eusebius's Greek writings left the East mired in Caesaropapism, or even state-worshipping autocracy. ${ }^{135}$ If Augustine recognized the prophesied millennium in the church, it only made sense to suppose Eusebius-the "herald of Byzantinism"-identified it with the state. Such ideas have become ingrained in the historiography so that they have persisted even after the dissipation of the political circumstances that gave rise to them.

However, such misinterpretations must finally be put to rest. The tendency to attribute to Eusebius an eschatology bound up with the ruling order not only distorts the modern understanding of the ideology of the Byzantine Empire and medieval Orthodox Church, but it also reduces to a caricature the thought of one of late antiquity's most learned thinkers. Eusebius was a historian who understood history not as a random sequence of events but as imbued with patterns and a purpose reflecting the will of God. No doubt, Eusebius became an optimist as he witnessed a fruitful cooperation between the Christian Church and the Roman state under Constantine, and he hoped this situation would continue under Constantine's sons. Eusebius saw the

the Third Rome' as Historical Ghost," in Byzantium: Faith and Power (1261-1557); Perspectives on Late Byzantine Art and Culture, ed. Sarah T. Brooks (New Haven, Conn.: Yale University Press, 2006), 170-179.

${ }^{132}$ Cyril Toumanoff, "Caesaropapism in Byzantium and Russia," Theological Studies 7, no. 2 (May 1946), 213-243; and Arnold J. Toynbee, "Russia's Byzantine Heritage," in Civilization on Trial (New York: Oxford University Press, 1948), 148-163.

${ }^{133}$ Podskalsky, Byzantinische Reichseschatologie, 3, cites Erik Peterson as a methodological model. Podskalsky proposes that Peterson's "exposure" of Eusebius's eschatology as mere political propaganda could be applied to Byzantine eschatology as a whole. Moreover, Podskalsky, in Byzantinische Reichseschatologie, 1, notes that his Lizenziatsarbeit, produced ten years earlier, was on millenarianism in the writings of Vladimir Lenin, and that his current project developed out of an interest in how Bolshevik thought was shaped by Russia's Byzantine legacy.

${ }^{134}$ One of the early and extremely influential contrasts between Augustine and Eusebius was set up by Peterson in his Der Monotheismus (Peterson also dedicated the book to Augustine, included a quotation from Augustine as epigraph, and ended the preface to first edition with a prayer to him). Markus, Saeculum, 49-56, built on Peterson's juxtaposition of Eusebius and Augustine.

${ }^{135}$ Such simplistic contrast between West and East is not found in Peterson's or Markus's juxtaposition of Augustine and Eusebius, but it is explicit in the work of other scholars. See, for example, F. Edward Cranz, "De civitate Dei, XV, 2, and Augustine's Idea of the Christian Society," Speculum 25, no. 2 (April 1950): 221: "The contrast between Eusebius and Augustine is historically significant as broadly typical of the contrast between Greek East and Latin West. In Byzantium, and even in later Russia, men thought fundamentally in terms of a single, all-embracing Christian society under the headship of emperor or czar. But in the West, throughout the ancient period, the city of God and the empire were kept distinct." Later, Cranz published an influential study of Eusebius: F. Edward Cranz, "Kingdom and Polity in Eusebius of Caesarea," Harvard Theological Review 45, no. 1 (January 1952): 47-66. 
hand of God at work in the reign of Constantine, just as he saw it at work in all of history. But the Roman Empire was only a historical means; it was not the end of history. It is high time to abandon the idea that Eusebius subscribed to a realized eschatology, along with the widely repeatedly assertion that Eusebius was the source of Byzantine imperial eschatology (if such a phenomenon ever actually existed at all).

Christopher Bonura received his PhD from the Department of History at University of California, Berkeley in 2019. His dissertation explored the reception of the theme of the four kingdoms from the Book of Daniel in late antique and early Byzantine political theory.

Cite this article: Bonura, Christopher. "Eusebius of Caesarea, the Roman Empire, and the Fulfillment of Biblical Prophecy: Reassessing Byzantine Imperial Eschatology in the Age of Constantine." Church History 90, no. 3 (September 2021): 509-536. https://doi.org/10.1017/S0009640721002158. 